NBER WORKING PAPER SERIES

EMOTIONAL JUDGES AND UNLUCKY JUVENILES

\author{
Ozkan Eren \\ Naci Mocan \\ Working Paper 22611 \\ http://www.nber.org/papers/w22611 \\ NATIONAL BUREAU OF ECONOMIC RESEARCH \\ 1050 Massachusetts Avenue \\ Cambridge, MA 02138 \\ September 2016
}

\begin{abstract}
We thank Janet Currie, Caroline Hoxby, David Figlio, Barry Hirsch, Daniel Millimet, Madeline Mocan, Greg Upton, Jim Kleinpeter, James Garand, Richard Boylan, Duha Altindag, Randi Hjalmarsson, Jeff Butler, Leyla Mocan, Michael Malinowski, John Palmer, Peter Lewisch and seminar participants at Georgia State University, University of Manitoba, American University, Spanish Law and Economics Association Meetings in Lisbon, Portugal, the Economics of Litigation Meeting in Montpellier, France, NBER's Children's Program and Education Program Joint Meeting in Washington DC, and the European Economic Association Meetings in Geneva, Switzerland for helpful comments. We also thank the Office of Social Service Research and Development (OSSRD) in the College of Human Sciences and Education at Louisiana State University for guidance with the data. Masayaki Onda, Suneye Holmes and Han Yu provided excellent research assistance. The views expressed herein are those of the authors and do not necessarily reflect the views of the National Bureau of Economic Research.
\end{abstract}

NBER working papers are circulated for discussion and comment purposes. They have not been peer-reviewed or been subject to the review by the NBER Board of Directors that accompanies official NBER publications.

(C) 2016 by Ozkan Eren and Naci Mocan. All rights reserved. Short sections of text, not to exceed two paragraphs, may be quoted without explicit permission provided that full credit, including () notice, is given to the source. 
Emotional Judges and Unlucky Juveniles

Ozkan Eren and Naci Mocan

NBER Working Paper No. 22611

September 2016

JEL No. D02,D03,J15,J71,K4,K41

\begin{abstract}
Employing the universe of juvenile court decisions in a U.S. state between 1996 and 2012, we analyze the effects of emotional shocks associated with unexpected outcomes of football games played by a prominent college team in the state. We investigate the behavior of judges, the conduct of whom should, by law, be free of personal biases and emotions. We find that unexpected losses increase disposition (sentence) lengths assigned by judges during the week following the game. Unexpected wins, or losses that were expected to be close contests ex-ante, have no impact. The effects of these emotional shocks are asymmetrically borne by black defendants. We present evidence that the results are not influenced by defendant or attorney behavior or by defendants' economic background. Importantly, the results are driven by judges who have received their bachelor's degrees from the university with which the football team is affiliated. Different falsification tests and a number of auxiliary analyses demonstrate the robustness of the findings. These results provide evidence for the impact of emotions in one domain on a behavior in a completely unrelated domain among a uniformly highly-educated group of individuals (judges), with decisions involving high stakes (sentence lengths). They also point to the existence of a subtle and previously-unnoticed capricious application of sentencing.
\end{abstract}

Ozkan Eren

Department of Economics

Louisiana State University

2305 Business Education Complex

Baton Rouge, LA, 70803

oeren@1su.edu

Naci Mocan

Department of Economics

Louisiana State University

3039 BEC

Baton Rouge, LA 70803-6306

and NBER

mocan@1su.edu 


\section{Emotional Judges and Unlucky Juveniles}

\section{Introduction}

It has been documented that emotions in one domain influence decisions in a completely unrelated domain. For example, sunshine improves mood (e.g. Schwarz and Clore 1983), and there is a positive relationship between sunshine and stock market performance (Kamstra et al. 2003, Hirshleifer and Shumway 2003). Edmans et al. (2007) show that controlling for pre-game expected outcome, there is a short-lived but significant stock market decline after a loss of an international soccer games (e.g. a World Cup game) in the country of the national team that lost the game, presumably because the results of such important games drive the moods of the residents of the country. More generally, it has been shown that emotions have powerful impacts on judgments, decisions and choices. Anger and sadness can influence judgments (Bodenhausen et al. 1994, Keltner et al. 1993). When one's sense of well-being is low, one spends more time focusing on negative attributes of others (Forgas 1995), and feelings of disgust can intensify the extent of moral condemnation (Schnall et al, 2008). As summarized by Lerner et al. (2015), "incidental anger triggered in one situation automatically elicits a motive to blame individuals in another situation even though the targets of such anger have nothing to do with the source of the anger (Quigley \& Tedeschi 1996). Moreover, carryover of incidental emotions occurs without awareness."

In this paper we test the impact of emotional influences using naturally-occurring micro data. We investigate whether emotional shocks, experienced by a highly-educated group of individuals, have any impact on these individuals' professional behavior which, by law, should be free of personal feelings and biases. Specifically, we examine the effects of emotional shocks associated with unexpected outcomes of football games played by a prominent college team 
- Louisiana State University (LSU) - on all judicial decisions handed down by judges in Louisiana's juvenile courts between 1996 and 2012.

We employ the Las-Vegas pregame point spread as fans' (judges in our case) rational expectations about the outcome of the game. To the extent that pregame point spread provides efficient prediction of game outcomes, controlling for the spread allows us to interpret any differential impact between a win and a loss as the causal impact of the game outcome (Card and Dahl 2011). A key background to our analysis is the fact that LSU football team, with its long and successful history in college football, has an enormous group of loyal followers. The fan base of the team goes well beyond the student body of the university: average attendance to home games was around 92,500 between 1996 and 2012. ${ }^{2}$ Clotfelter (2015) details the extent of fans' devotions and their emotional ties to college teams.

By special permission from Louisiana Department of Public Safety and Corrections, Youth Services, Office of Juvenile Justice, we obtained access to the universe of defendant files from 1996 to 2012. For each file, we have basic demographic information on the defendants, details of the offense committed, as well as information on the disposition (sentence) length and disposition type (i.e., custody or probation). The files also contain identifiers that allow us to gather information on the race, gender, age, and party affiliation of judges who adjudicated these cases, as well the law school and the undergraduate institution from which they graduated. We

\footnotetext{
${ }^{2}$ Describing LSU football just as an event would be a huge understatement for the residents of the state of Louisiana. Devotion to LSU football is deeply ingrained into the culture of the state. Weddings are scheduled based on LSU games, convention halls and similar organizations are besieged by phone calls the moment LSU schedule for the following football season is finalized, and charitable organizations have their fund-raising events scheduled on the nongame weeks (Feinswog 2013). Note that the popularity of college football in the U.S. is not limited to Louisiana. Average attendance to college football games among all Division I teams was around 45,000 in 2012. Average attendance among the top-20 teams was more than 75,000. Moreover, around 216 million viewers tuned in to watch the regular college football season with another 126 million watching the bowl games (National Football Foundation 2013).
} 
link our defendant-judge paired data to the record of the LSU football team over the same time period to analyze the impact of unexpected game outcomes on judicial decision.

Our results provide important insights. First, we find that upset losses (i.e., losses by LSU football team when they were expected to win) increase the disposition length imposed by judges on juvenile defendants. In contrast, upset wins (i.e., games won by LSU when they were expected to lose) have no significant impact on the disposition length set by judges. Similarly, close losses (games lost by LSU when the outcome was uncertain ex-ante) have no impact. A number of robustness analyses confirm our results. A placebo test based on unexpected game results of other prominent college football teams shows that non-LSU games have no impact on judge behavior. Similarly, judicial decisions in a given week are not impacted by LSU games played the following week. Further examination of the data suggests that these results are unlikely to be driven by emotional reactions of prosecutors or defense attorneys, by defendant socio-economic background, or by potential courtroom misconduct of juveniles that could have prompted judges' agitation. Most importantly, we find that the results are driven entirely by those judges who have received their bachelor's degrees from LSU.

Second, analyses based on juvenile defendants' race provide information pertaining to disparity of treatment and sheds light on the application of the equal protection clause of the law. Our results suggest that the brunt of the burden of judges' reaction is borne by black defendants. ${ }^{3}$ We also find that the impact is larger for trials that take place after an upset loss in an important game (when LSU was ranked in the top 10 of the Associated Press Rankings).

The results are important for a number of reasons. First, they provide evidence for the impact of emotions on decisions in an environment where the decision-makers are uniformly

\footnotetext{
${ }^{3}$ Adjusting for observable defendant attributes and judge fixed effects, there is no difference in sentence lengths between black and white defendants in the absence of an unexpected LSU loss.
} 
highly educated, and when the decisions in question should have been bound by institutional restrictions and ethics. Specifically, application of the relevant legal principles to the facts of the case is expected to eliminate arbitrary and capricious decisions by judges. Yet, we find that the severity of sentences handed down by judges are impacted by the results of a football game for those judges who are more likely to be emotionally attached to the team. This finding underscores the importance of emotions in decision making even in a high-stake environment. The results are also consistent with models of expectation-based, reference-dependent preferences which postulate that economic agents assess the outcome of a choice by its departure from a reference point that is determined by the probabilistic beliefs about that outcome held in the past (Kahneman and Tversky 1979; Koszegi and Rabin 2006).

The second contribution of the paper is related to the investigation of whether the judicial process is unbiased. It is well-documented that inequalities exist in the application of the law to different groups of individuals (e.g., Argys and Mocan 2004; Shayo and Zussman 2011; Abrams et al. 2012; Alesina and La Ferrara 2015). A different layer of complication arises in the application of the law because some of the capricious judicial decisions seem arguably unintentional. For example, Danziger et al. (2011a) show that the propensity of judges to make favorable parole decisions goes down significantly as they adjudicate the cases sequentially; and that judges' propensity to be lenient jumps up after a food break. Their finding suggests a "decision fatigue" of judges that results in differential treatment of defendants based on the time of day their case is adjudicated. ${ }^{4}$ In this paper we find that the impact of an upset loss is observed

\footnotetext{
${ }^{4}$ Weinshall-Margel and Shaphard (2010) raised issues about the randomness of the order in which the cases are seen by judges and the timing of the meal breaks. Also see the response of Danziger et al. (2011b). Similarly, but in a different domain, Linder et al. (2014) find that primary care physicians' propensity to prescribe antibiotics for acute respiratory infections (an inappropriate decision) goes up as the clinic session gets longer, indicating that cognitive fatigue impairs judgment. Chen et al. (2015) find negative autocorrelation in the decisions of judges, loan officers and baseball umpires that is unrelated to
} 
immediately after the game (on Monday), and it lasts for one work-week. Thus, it cannot be attributed to decision fatigue of judges. It is, however, consistent with the hypothesis that emotional stress is responsible for judges' behavior. Our finding that the results are driven entirely by those judges who have received their bachelor's degrees from LSU indicates that emotional shocks are in fact the driver of this behavior. ${ }^{5}$

Although harsher punishment handed down by judges is not deliberate (because it is triggered by an emotional shock), we find some evidence that black defendants bear much of the burden of judges' wrath due to this emotional shock, which hints at a negative predisposition towards black defendants. This result, coupled with the fact that there are no race related differences in the disposition length in the absence of judges' emotional stress, is suggestive of the existence of a subtle, and previously-unnoticed, bias in sentencing. ${ }^{6}$

The remainder of the paper is organized as follows. Section 2 discusses the institutional settings. Section 3 presents the data. Section 4 describes the econometric methodology. Section 5

the merits of the cases. They report that this behavior is consistent with decision-makers suffering from gambler's fallacy, i.e., underestimation of the likelihood of streaks occurring by chance (Rabin and Vayanos 2010; Tversky and Kahneman 1974).

${ }^{5}$ The impact of mood changes, triggered by unexpected losses of sports teams, has been documented in other domains. For example, Edmans et al. (2007) show that there is a short-lived stock market decline after the national soccer team loses an international soccer game. The authors show that this result cannot be explained by economic factors and stock market dynamics, and attribute it to the change in investor mood due to the loss of the national team. Card and Dahl (2011) find that unexpected losses of home teams in the National Football League (NFL) increase the domestic violence rates by men in the city in which the team is located. Chen and Spamann (2014) show that asylum grant rates in U.S. immigration courts differ by the success of the court city's NFL team. Healy et al. (2010) investigate the electoral impact of local college football games and show that a win during the 10 day window before the election day causes the incumbent to receive a higher percentage of the vote in the Senate, gubernatorial and presidential elections. In a related, but different domain, Lindo et al. (2012) find that the grade point average of male students declines in relation to the grade point average of female students at the University of Oregon during the football seasons when the university's football team is successful, which is attributed to increased alcohol consumption of male students in response to the team's success.

${ }^{6}$ There are a variety of other outside factors, identified by previous research, that are unrelated to the merits of the case but ends up affecting sentencing decisions. See, for example, Lim et al. (2015) and Philippe and Ouss (2015) for the relationship between media and sentencing decisions. 
presents the results. Conclusions are provided in Section 6.

\section{Institutional Setting}

In Louisiana, youth through age 17 may enter the juvenile justice system when they are accused of committing a crime and arrested or referred by the police to a juvenile court. ${ }^{7}$ Having received a formal complaint from a local law officer, the District Attorney's (DA) Office must decide whether or not to petition the case to the court. Prosecutors may choose not to do so because of lack of sufficient evidence. The DA's Office may also choose to enter into an informal agreement (diversion program) with the juvenile and the parents to prevent incarceration. This occasionally entails the child participating in community service, restitution, or treatment and complying with certain behavioral requirements such as satisfactory school attendance (Louisiana Children's Code CHC 631). Alternatively, prosecutors may proceed with a petition to the court. In this situation the case moves to adjudication, and the disposition, which is similar to a sentence in the adult courts, must be determined by a juvenile court judge (Louisiana Children's Code CHC 650-675). Under the provisions of the Louisiana juvenile justice system, a computer generated random allotment (open to public) is implemented on a daily basis by the Clerk's office for all cases filed in each district court (Rules for Louisiana District Courts, Chapter 14, Appendix 14.0A, various years). Thus, cases are randomly assigned to judges within each district court. ${ }^{8}$

A judge may simply dismiss the case if the prosecutor is unable to provide evidence to find the youth delinquent. The juvenile would then be found not guilty and does not enter into the

\footnotetext{
${ }^{7}$ Children under age 10 are addressed through the Families in Need of Service programs.

${ }^{8}$ Random assignment of judges to cases excludes charges involving heinous crimes such as first-degree murder.
} 
juvenile justice system. ${ }^{9}$ If the judge finds the defendant guilty, the judge has to then make a disposition decision. This involves placing the juvenile in custody (secure or non-secure) or on probation. In either case, the judge also has to assign the disposition length (sentence length). Judges are responsible for weighing the severity of the offense committed and the prior offense history of the youth. Louisiana Children's Code requires that crimes of first degree murder, second degree murder, aggravated or first degree rape and aggravated kidnapping receive a mandatory disposition of secure custody until the age of twenty-one years without the benefit of parole, probation, suspension of imposition or execution of sentence, or modification of sentence (Louisiana Children's Code CHC 897.1). ${ }^{10}$ In general, the judge will impose the least restrictive disposition consistent with the circumstances of the case, the health and safety of the child, and the best interest of the society (Louisiana Children's Code CHC 683). ${ }^{11}$ Judges can set a maximum duration of disposition up to the youth's $21^{\text {st }}$ birthday. ${ }^{12}$

\section{Data}

\subsection{Defendant Data and LSU College Football Team Records}

The defendant data for this study are obtained from the Louisiana Department of Public Safety and Corrections, Youth Services, Office of Juvenile Justice (OJJ) and include all case records from 1996 to 2012 in which juvenile was found to be delinquent. For each case record,

\footnotetext{
${ }^{9}$ We will return to this point later in the paper.

${ }^{10}$ There are only 32 of such cases during the sample period. Because a guilty verdict in these cases requires mandatory sentencing, they are excluded from the analysis.

${ }^{11}$ In setting the appropriate disposition, judges may also consider the predisposition investigation report prepared by probation officers involving information about youth, their risk to public safety and their needs (Louisiana Children's Code CHC 680).

${ }^{12}$ Statutory exclusion laws apply to certain offenses to youth over 14 in the state of Louisiana.
} 
we have information on both the juvenile defendant and the case itself. Information on the defendants include the race, gender, age, parish of residence, parish of offense, the exact statute offense committed, the date the individual was admitted into the juvenile system and a unique individual identifier. The case data include information on the date the juvenile was disposed before the judge, the judge's decision on the case (the disposition type and disposition length), the court in which the disposition was held, and the identifier of the judge. In order to circumvent any potential confounding effects that may arise from multiple offenses and/or criminal history of the juvenile, we limit our attention to first-time delinquents ages 10 through 17 who were convicted for only one statute offense. Using the judge identifiers provided in the OJJ administrative data, we also gathered information on judges' race, gender, political party affiliation, age, the law school from which they graduated, and the university from which they have obtained their undergraduate degree. ${ }^{18}$

We link our defendant-judge data to LSU college football team records. Specifically, we analyze all dispositions handed down by judges during the work week following a Saturday game throughout the college football season and post season (i.e., bowl games). We analyze the decisions during the 5-day work week (Monday through Friday) following the game, although later in the paper we also investigate whether the impact of the game outcome lasts longer than a week. Having imposed these restrictions and excluding 32 cases involving first and second degree murder and aggravated rape, we end up with a sample of 8,228 unique case (juvenile) records from a total of 207 judges. ${ }^{19}$

\footnotetext{
${ }^{18}$ Information on judges is based on data from Louisiana District Judges Association Periodicals (19562000), as well as phone conversations with the relevant parish clerk's office.

${ }^{19}$ To minimize any potential confounding effects that may arise due to measurement error and outliers, we also exclude defendants whose disposition length is more than the $99^{\text {th }}$ percentile of the disposition length distribution. This restriction applies to sentence lengths longer than 1,857 days and to 83 defendants. The
} 
Table 1 presents the descriptive statistics for juveniles and judges. Panel A displays juvenile attributes while Panel B presents judge characteristics. The average disposition length is about 513 days. Figure 1 displays the distribution of disposition length. There is bunching at about half-year thresholds (i.e., half a year, one year and one and a half year) with a median of 366 days. The spikes in disposition length are driven by judges commonly choosing disposition lengths at half-year intervals for high frequency offenses such as simple burglary, possession of drugs, simple battery, and disturbing the peace. ${ }^{20}$ However, it should be noted that there is no mandatory sentencing guidelines and judges exercise considerable discretion in sentencing. For example, the average disposition length of disturbing the peace is 307 days, with a standard deviation of 228, and the mean (standard deviation) disposition length of simple battery is 348 (193) days.

The average incarceration rate is 26 percent. Put differently, 26 percent of those who are found guilty of the charge are placed on (secure or non-secure) custody. This is similar to the national average (25 percent in 2011) among all adjudicated delinquent cases (Hockenberry and Puzzanchera 2014). ${ }^{21}$ Sixty-two percent of the convicted juveniles are black, while 36 percent are white.

results of the paper remain intact if we drop this restriction and use all observations in the data, or if we impose a symmetric restriction and drop defendants whose disposition length is less than the $1^{\text {st }}$ percentile of the disposition length distribution as well. See Section 5.6 for several different robustness checks.

${ }^{20}$ While the football season spans late-August to December, there is nothing different about this time of year in comparison to the rest of the year in terms of the composition of offenses. The five most frequent offenses between the beginning of September and the end of December, in descending order, are ungovernable $(10.3 \%)$, simple burglary $(8.9 \%)$, simple battery $(8.4 \%)$, possession, manufacturing and distribution of drugs $(6.8 \%)$, and disturbing the peace $(5.0 \%)$. The five most frequent offenses during January-August, in descending order, are: ungovernable (10.2\%), simple battery $(8.4 \%)$, simple burglary $(8.0 \%)$, possession, manufacturing and distribution of drugs $(7.5 \%)$, and disturbing the peace $(5.5 \%)$.

${ }^{21}$ As for non-incarceration disposition options, probation forms the backbone of the Louisiana's juvenile justice system. Our definition of incarceration status (secure and non-secure custody) is standard in the literature (e.g., Aizer and Doyle 2015). 
The overwhelming majority of judges ( 88 percent) are white, and only about 23 percent are female. Average age of judges is 56, and about 73 percent of judges are affiliated with the Democratic Party. ${ }^{22}$ It is interesting that in terms of observable characteristics, the judge sample used in this study is similar to that reported in Abrams et al. (2012) for adult courts in Cook County of the state of Illinois. Note also that 47 percent of the judges graduated from LSU law school, while about one-third have received their bachelor's degree from LSU. ${ }^{23}$

Table 2 reports win-loss record of the LSU football team for the seasons 1996 to 2012. There is non-trivial variation from year to year. For example, LSU had a disappointing season with a 3-8 win-loss record in 1999, while the record in 2000 was 8 wins and 4 losses.

\subsection{LSU College Football Team's Predicted and Actual Outcomes}

Spread betting on professional and college football games is organized through Las Vegas bookmakers. The market assessment of the outcome of a game is assumed to be contained in the closing value of the spread. For example, if the pregame point spread is -5 for LSU against another team, this means that LSU is predicted to win by 5 points or more. Card and Dahl (2011) provide credible evidence on efficient prediction of the pregame point spread on game outcomes in the NFL. To build upon this evidence, we collected data on pregame point spreads and final scores of all LSU college football games for seasons from 1996 to 2012 and ran a simple regression of the actual spread on the predicted spread (closing value of the pregame point

\footnotetext{
${ }^{22}$ In empirical analyses, we use the age of the judge at the disposition date. For summary statistics, we report the judge's age at the last observed disposition date.

${ }^{23}$ The undergraduate institutions from which the judges have graduated could be determined in case of 180 judges.
} 
spread). ${ }^{24}$ The coefficient estimate (standard error) from this exercise is $0.98(0.07)$ with a $R^{2}$ value of 0.49 . Figure 2 plots the relationship between actual and predicted point spread. It is important to note that the estimated effect on the predicted spread for LSU football games is almost identical to that reported in Card and Dahl (2011) for the games played by six NFL teams during the 1995-2006 seasons.

Having shown support for efficient prediction hypothesis of the point spread on game outcomes in college football, our next step is to divide the point spread into segments. Following Card and Dahl (2011), we define ex ante classification of LSU college football games as (i) predicted win if point spread is -4 or less, (ii) predicted close if point spread is between -4 and 4 , and (iii) predicted loss if point spread is 4 or more. Our results, however, are robust to using different spread value cutoffs (discussed in section 5.6).

Our sample includes all dispositions during the weekdays following a Saturday game of the regular college football season between 1996 and 2012, as well as post-season bowl games that are played on Saturdays. LSU has played 184 Saturday games during this time span, but betting information is not available for five of these games. Thus, we utilize the remaining 179 games -- or about 85 percent of all games played by LSU over 16 years (Table 3, Panel A). As shown in Panel B, LSU football team won 133 of these 179 Saturday games, which translates into a win rate of 74 percent. Of these 179 games, 122 (68 percent) were predicted wins, 29 (16 percent) were predicted close games and 28 (16 percent) were predicted losses. As displayed at the lower section of Panel B of Table 3, LSU lost 14 of the 122 games in which it was favored to win by four or more points: these are upset losses. LSU lost about 48 percent of the games that were predicted to be close contests: these are close losses; and LSU won 10 of the 28 games

${ }^{24}$ Pregame point spread data come from an online betting agency (www.goldsheet.com) and game statistics are obtained from LSU athletics department (www.lsusports.net). 
(almost 36 percent) in which it was predicted to lose by four or more points: these are upset LSU wins.

The total number of dispositions associated with game outcomes is reported in [brackets] beneath each category in Panel B of Table 3. There were 781 dispositions during the 14 work weeks after upset losses, generating an average of 56 dispositions per week. There were 44 weekly dispositions, on average, associated with close losses (612 total dispositions after 14 close losses), and there were 55 dispositions per week after upset wins. Note that the number of dispositions handled by judges each week is a function of the flow of cases coming in to the docket, and it takes an average of 60 days between the petition hearing (following the motion of the district attorney) and the decision of the judge at the disposition trial. Thus, the alleged crimes committed by these juveniles and the charges filed against them took place at least two months before the relevant LSU game. Put differently, the difference in weekly average dispositions is not a function of any potential concurrent local criminal activity at the time of judge's decision.

Figures 3-5 display the frequency distribution of opponent teams for all Saturday games disaggregated by predicted spreads and actual outcomes of the games. Unexpected game outcomes generally involve opponent teams that are known to be LSU's historical rivals such as the University of Alabama and University of Florida. Finally, LSU college football team was ranked in the top 10 based on Associated Press rankings for 86 games (48 percent) played on Saturdays over the sample period.

\section{Empirical Methodology}

To estimate the impact of emotional shocks generated by unexpected wins or losses on disposition length imposed by judges, we specify the following equation: 


$$
\begin{aligned}
D_{i j d k s}=\lambda_{0}+ & \lambda_{1} 1\left(S_{k-1 s} \leq-4\right)+\lambda_{2} 1\left(S_{k-1 s} \leq-4\right) 1\left(y_{k-1 s}=0\right)+\lambda_{3} 1\left(-4<S_{k-1 s}<4\right) \\
& +\lambda_{4} 1\left(-4<S_{k-1 s}<4\right) 1\left(y_{k-1 s}=0\right)+\lambda_{5} 1\left(S_{k-1 s} \geq 4\right) \\
& +\lambda_{6} 1\left(S_{k-1 s} \geq 4\right) 1\left(y_{k-1 s}=1\right)+X_{i j d k s} \beta+\eta_{j}+\gamma_{d}+\delta_{\mathrm{k}}+\theta_{s}+\epsilon_{i j d k s}
\end{aligned}
$$

where $D_{i j d k s}$ is the disposition length for defendant $i$ set by judge $j$ on day $d$ of week $k$ in season $s ; S_{k-1 s}$ is the observed pregame point spread for a Saturday game and is defined as indicator functions for the three ranges of the spread value. In this set-up, games are classified as close match-ups if the point spread in the betting market is between -4 and +4 . Thus, $1\left(S_{k-1 s} \leq-4\right)$ takes the value of one if LSU was predicted to win the game that was played on the Saturday immediately preceding the work week $k$ during season $s$ by a margin of at least four points Similarly, if the point spread is 4 or more, the indicator function $1\left(S_{k-1 s} \geq 4\right)$ takes the value of 1, implying that LSU was predicted to lose that game. As detailed in the Section 5.6, using different cutoffs for the point spread did not alter the results. $y_{k-1 s}$ is another indicator function that takes the value of one for LSU football team's victory. $X_{i j d k s}$ represents the vector of observed juvenile (i.e., gender, race, age and detailed offense type), judge (i.e., gender, race, party affiliation and age) and game (i.e., home/bowl game status) characteristics, $\eta_{j}$ is the set of judge fixed effects, $\gamma_{d}, \delta_{k}$ and $\theta_{s}$ denotes day of the week, week, and season effects, respectively, and $\epsilon_{i j d k s}$ is the error term. Standard errors are clustered at the judge level. The results remain intact if we instead cluster at the season $\times$ week or at the season $\times$ week $\times$ day of the week level.

The coefficient estimates for $\lambda_{2}, \lambda_{4}$ and $\lambda_{6}$ measure the effects of an upset loss, a close loss and an upset win on disposition length set by the judges, respectively. In estimations below, we treat predicted win $1\left(S_{k-1 s} \leq-4\right)$ as our base category. As discussed in the robustness section, treating nongame (bye) weeks as the base category produces very similar results. 
The key identifying assumption underlying this framework is that the outcome of a college football game is as good as random, conditional on pregame point spread. Put differently, to the extent that Las Vegas spread provides efficient prediction of the LSU college football game outcomes, controlling for the point spread in Equation (1) allows us to tease out the effects of emotional cues of game outcomes. ${ }^{25}$

\section{Results}

\subsection{Baseline Results}

Table 4 presents the baseline results. Column (1) displays the results of a parsimonious model which includes only spread indicators (treating predicted win as the base category), interactions of spread indicators with win/loss variables and indicators for the day of the week, week and season. The results show that an upset loss leads to a 37 day increase in the disposition length set by the judge. Turning to other coefficient estimates associated with game outcomes (second and third rows), we observe that the estimated effect from a close loss is positive, but it is imprecisely estimated. On the other hand, row (3) shows that an upset win generates a 15 day decrease in disposition length, although this effect is statistically insignificant.

We extend our baseline specification by incrementally adding controls for observable judge (column 2), juvenile (column 3) and game (column 4) characteristics. The coefficient estimates on the effects of upset losses, close losses and upset wins remain intact. Column (5)

\footnotetext{
${ }^{25}$ It should be noted that random assignment of juveniles to judges is not necessary in this design to obtain unbiased estimates of the causal effects of game outcomes. However, because the Louisiana juvenile court system employs random assignment of case files to judges, we investigated whether random assignment holds true in the data; and we found strong evidence for it. For example, controlling for the unit of randomization (year-by-court fixed effects), a regression of black defendant indicator on a black judge indicator yields a coefficient (standard error) estimate of 0.007 (0.022). Similarly, a regression of female defendant indicator on female judge indicator produces a coefficient (standard error) estimate of 0.005 (0.024).
} 
demonstrates that adding detailed measures of offense types (171 offense fixed effects) and judge fixed effects to our extended specification in column (4) does not alter our findings either.

A comparison of our most extensive specification in column (5) of Table 4 with our baseline specification in column (1) shows that the estimated effect on an upset loss in row (1) does not change either in magnitude or in statistical significance in any meaningful manner. ${ }^{26}$ Column (5) of Table 4 demonstrates that an upset loss increases disposition length set by the judges by about 35 days. Taking the average disposition length (513 days) as the baseline, this magnitude corresponds to a 7 percent increase. The impact of close losses and upset wins on disposition length are very small in magnitude and they are not statistically different from zero (column 5, Table 4).

Although there exists evidence in the psychology literature pointing out a relatively long lasting (almost over a week) association between emotional shocks following major sporting events (Phillips 1983; Miller et al. 1991), it is conceivable that the emotional impact attributable to an upset loss fades out as judges proceed through the week. To address this potential transitory nature of emotional shocks associated with college football game outcomes, we interact our three key measures of upset loss, close loss and upset win with an Early Week Day indicator. Table 5 presents the results from this exercise for our most extensive (and preferred) specification. We treat the Early Week Day indicator to only include Monday in the first column, while Monday through Wednesday are considered early weekdays in the second column of Table 5. The interaction term for the effect of an upset loss with early week indicator is negative in the first column and neither one is statistically significant. The effects of a close loss and an upset win continue to be statistically indistinguishable from zero. Thus, the evidence suggests that the

\footnotetext{
${ }^{26}$ This is reassuring because college game outcomes, conditional on pregame point spread, are expected to be as good as random.
} 
causal impact on disposition length (i.e. sentence severity) of judges' negative emotions, triggered by an upset loss of a football game, lasts for an entire week after the game.

To investigate whether the impact of game outcomes on judges' decisions lasts for two weeks, we modify our model by including spread indicators and their interactions with win/loss variables from the week before $\left(S_{k-2 s}\right.$ and $\left.y_{k-2 s}\right)$. This specification can be estimated using the weeks in which LSU football team has played games in consecutive weeks. The results are provided in Table 6. Column (1) replicates our benchmark regression. This is the same regression reported in column (5) of Table 4, but it is estimated using the sample based on games played in consecutive weeks. ${ }^{27}$ Column (2) of Table 6 reports the model where the disposition length assigned by judges is explained by the spread and game outcomes pertaining to the previous week's game. No coefficient is statistically different from zero, indicating that the result of a game played on a given Saturday has no impact on judges' decisions during the second week following the game. Finally, the model reported in column (3) investigates the extent to which upset losses have a lingering effect beyond the first week after the game by including both the information about the game played in the immediately preceding Saturday and the previous Saturday. The results show that an upset loss has an impact on the decisions made by judges during the week following the game, but the result of the previous week's game has no impact. ${ }^{28}$ The upshot is that, the emotional impact of an upset loss lasts for one week, but no longer.

In summary, our baseline specifications provide three important insights. First, we detect a large and statistically significant effect from an upset loss on disposition length imposed by judges. On the other hand, losses that were expected to be close contests ex ante have no

\footnotetext{
${ }^{27}$ That is, the weeks before and after the nongame weeks are omitted.

${ }^{28}$ Treating nongame weeks (bye weeks) as the omitted category and including full set of interactions between ex ante classification of games and outcomes of games yield similar results.
} 
statistically significant impact. This implies that less anticipated losses generate stronger negative cues relative to more anticipated ones. A test of equality between the coefficient estimates of the effect of upset loss and that of close loss in Column 5 of Table 4 is rejected ( $p$-value $=0.04$ ). Second, our results indicate that judges show emotional reactions to an upset loss while they do not do so in case of an upset win. A test of equality between the coefficient estimates of the effect of upset loss and upset win from Column 5 of Table 4 is rejected ( $p$-value $=0.04){ }^{29}$ Finally, we do not find evidence for quick decay of emotional cues associated with college football game outcomes. The effect of an upset loss persists over the entire week, although it does not carry over to the following week. ${ }^{30}$

\subsection{High-Stake Games, Types of Criminal Offenses, and the Race of the Juvenile}

To further improve our understanding of behavioral responses, we explore judges' emotional reactions to unexpected college football game outcomes along three dimensions: (i) the impact on disposition length by the importance of the game, (ii) the impact by type of offense: felony vs. non-felony (minor), and (iii) the impact by the defendant's race.

Columns (1) and (2) of Table 7 report the results where the games are classified based on their importance. Specifically, we consider a game to be more important if LSU football team was ranked in the top 10 of the Associated Press rankings in the week prior to the game. The

\footnotetext{
${ }^{29}$ The asymmetry between the impact of negative and positive shocks lends support to loss aversion: agents value losses more than they value commensurate gains (Kahneman and Tversky 1979; Koszegi and Rabin 2006).

${ }^{30}$ Using aggregate level county data, Card and Dahl (2011) show that an upset loss leads to around 10 percent increase in the rate of at-home violence by men against their wives or girlfriends. Closes losses and upset wins, on the other hand, have little to no impact on domestic violence. The authors also show that violence is concentrated in a narrow time interval surrounding the end of the game. Comparing our results with Card and Dahl (2011), we find similar but more persistent effects of emotional cues to unexpected game outcomes. Several factors including but not limited to the unit of observation (judge vs. domestic abuser), outcome of interest (disposition vs. domestic violence) and nature of the data (micro vs. aggregate) may all contribute to the divergence in the results of these two natural experiments.
} 
results demonstrate that judges' reactions are harsher if the team suffers an unexpected loss when the team was ranked in the top-10 going into the game. This result is not surprising because losing a game is quite consequential towards national championship when the team is ranked in the top 10, and this is even more so if the team loses such a game when it was predicted to win. Such a loss generates 63 additional days longer disposition imposed by judges. On the other hand, the impact of an unexpected loss is 36 days and statistically not different from zero for relatively low-stake games. ${ }^{31}$

Columns (3) and (4) of Table 7 display the results where judges' emotional responses to unexpected game outcomes by the severity of the offense are explored. Using the OJJ's own classification system, we grouped the 171 offense types as felony and non-felony crimes. Judges seem to react somewhat similarly following an upset loss for both felony and non-felony offenses. The effect sizes are 5.4 and 7.2 percent, relative to their sample-specific averages, for juveniles who have committed felony and non-felony offenses, respectively. We continue to observe no statistically significant impact from a close loss or an upset win on disposition length set by the judge, irrespective of the offense type.

Looking at the effects by juveniles' race (columns 5 and 6, Table 7), we observe that an upset loss increases the disposition length by about 46 days for black defendants, which translates into an increase in sentence severity by almost 9 percent. The impact of an upset loss for white defendants is about one-sixth as large (about 8 days) and statistically not different from zero. These results suggest that the brunt of judges' emotional reaction is borne mostly by black

\footnotetext{
${ }^{31}$ When we examined the impact of emotional shocks by home game status, we find the effect of an upset loss to be more pronounced for home games. Specifically the coefficient estimates (standard error) are 45.332 (22.557) and 34.781 (39.474) for home and away games, respectively. None of the other coefficient estimates on game outcomes are different from zero.
} 
defendants. This disparity in sentencing following an upset loss implies unequal treatment of black defendants, triggered by an outside event, unrelated to the merits of the case.

It is important to note that when we run our benchmark regression, accounting for all factors employed in previous regressions (ranging from offense fixed-effects to judge fixedeffects, defender attributes) but omitting the variables related to football, we find that the coefficient of the variable for black defendants is -4.70 with a standard error of 7.87 . This specification indicates in the absence of the football effect average disposition lengths are not different between black and white defendants. ${ }^{32}{ }^{33}$ Yet, the results in columns (5) and (6) of Table 7 suggest that after having been exposed to an upset loss, judges treat black and white defendants differently and that much of the burden of the emotional trauma generated by the upset loss seems to fall on black defendants. ${ }^{34}$

\subsection{Is this Result because of Other Actors in the Courtroom?}

We argue that longer sentences stemming from an upset loss reflect judges' behavior. However, unexpected game outcomes may somehow affect the performance of defense attorneys or prosecutors and therefore the estimated effect of an upset loss may not solely reflect judge's behavior. For example, if the prosecutor recognizes that the judge is upset about the outcome of the football game that was played the previous weekend and that the judge may be harsher on the

\footnotetext{
${ }^{32}$ A simple test of equality of the mean sentence lengths between blacks and whites is rejected at the 5 percent level, underlying the importance of controlling for confounders.

${ }^{33}$ We also estimated this benchmark regression by including interaction terms for black defendant indicator with other control variables. The estimated coefficient on black defendant indicator was not different from zero.

${ }^{34}$ To further explore the source of racial disparity in sentencing, we interacted our measures of unexpected game outcomes with an indicator for judge's race and re-estimated the models reported in the last two columns of Table 7. In none of these additional specifications the interaction term was statistically different from zero.
} 
defendants as a result, the prosecutor may present the case against the juvenile with a more lenient predisposition. Conversely, prosecutors themselves may be upset about the game outcome and therefore they may be harsher on the defendants as well. To shed light on concerns about potential interventions of the prosecutors or defense attorneys, we examine the sensitivity of the results to the timing of adjudication and disposition (sentencing) trials.

Table 8 presents the results from this exercise. In column (1) we display the results obtained from the sample of defendants for whom the adjudication (guilty v. not guilty) and disposition (sentence length and sentence type) decisions were made during the same week. As before, the estimated impact of an upset loss is positive and statistically significant. In the second column of the table we limit our attention to case files for which the adjudication and disposition trial dates are at least one week apart. This sample consists of juveniles whose adjudication decision has been made at least one week before the disposition hearing (i.e., the decision on guilt vs. innocence was made before the football game was played). In other words, any influence the attorneys may have had on the adjudication outcome of this group of defendants took place before the football game, and the judge has made a sentencing decision after the game without the influence of the attorneys. If the game outcome has no impact on judge behavior, the estimated coefficient of an upset loss should be zero in this sample. Although we have a small sample of 1,314 observations that do not permit the coefficient to be estimated with precision, the point estimate of an upset loss on disposition length is far different from zero (column 2, Table 8). Thus, the results reported in columns (1) and (2) of Table 8 are consistent with the explanation that it is the emotional reaction of judges that is the driving force in extended sentencing.

Could the results be attributable to the attitude of the juvenile defendants in the courtroom? It can be argued that it is not the judges, but the juveniles who are the root cause of 
longer sentences they receive after an upset loss. More specifically, it could be the case that juveniles get distraught or depressed after an upset loss of the LSU football team, and as a result, when they appear in the courtroom for the sentencing hearing, they act in manners that would aggravate or irritate judges. Hence, it could be the courtroom behavior of juvenile defendants, due to an upset loss, that prompts judges to impose higher sentencing. We provide two counterarguments to this point. First, if this conjecture is true, one would expect all juveniles, regardless of race, be impacted by an upset loss in the same manner. There is no reason to expect black or white defendants to be more or less distraught about the game outcome to act more or less inappropriately in the court room. Yet, our results show that sentence lengths of black defendants are impacted by an upset loss, while there is no statistically significant impact on white defendants (columns 5 and 6, Table 7). Second, it is plausible that younger defendants might be more timid in the court room in comparison to older juveniles. Note that everybody in our sample is a first-time offender; so they all go through this experience for the first time. Nevertheless, to the extent that the courtroom experience in front of a judge is more intimidating for younger youths than older juveniles, the propensity to misbehave in front of the judge (due to an upset loss) would be lower for younger defendants. Thus, the impact of an upset loss should be zero (or at least smaller) for younger defendants in comparison to older ones. However, when we estimate the model by dividing the sample into two age groups (ages 15 or lower, and ages older than 15), we obtain similar coefficients. The impact of an upset loss is extra 34 days of sentencing for those defendants who are older than 15 ( $\mathrm{p}$-value $=0.10$ ); and the impact is 42 days among the sample of kids who are 15 or younger ( $\mathrm{p}$-value $=0.07$ ). To the extent that courtroom misbehavior is correlated with age, this result suggests that our findings are not driven by the behavior of juveniles in front of judges. 
It could be the case that juvenile defendants with lower socio-economic status are impacted by an unexpected LSU loss differently in comparison to their economically better-off counterparts. This can happen if, for example, poorer defendants are represented by attorneys who exhibit a lower degree of professionalism in the courtroom. Consequently, the performance of these attorneys may be negatively impacted by an unexpected LSU loss, whereas the attorneys of economically better-off defendants may not be impacted by football game results. Although we have no direct information on the socio-economic status of juvenile defendants, we could identify, for much of the sample, whether or not they were enrolled in school free lunch program. Enrollment in the free lunch program is an indicator of poverty, which enables us to gain some insights into potential differential impacts by defendants' poverty status. The coefficient of unexpected LSU loss in the sample of juveniles who are free school lunch recipients was 35.5 (standard error= 18.2). The estimated coefficient of an unexpected LSU loss was 30.2 (standard error=25.4) in the sample of defendants who are not free school lunch recipients. This result indicates that the identified impact of an upset loss is not a function of the socio-economic status of the defendants.

\subsection{Judges who have Bachelor's Degrees from LSU}

Our final and the most convincing evidence that the results are not driven by anyone other than the judges themselves is provided in columns (3) and (4) of Table 8. In these regressions we divided the sample into two segments: the cases handled by judges who have received their undergraduate degrees from LSU, and those judges whose bachelor's degrees have been obtained from a college or university other than LSU. Because we could identify alma maters of 180 of the 207 judges, sample sizes are somewhat smaller, but a striking result emerges. As shown in 
column (3) of Table 8, unexpected losses of the LSU football team prompts judges to impose sentences that are 74 days longer if these judges have received their undergraduate degrees from LSU. On the other hand, as displayed in column (4), the results of LSU football games have no impact on sentence lengths in the sample of judges who have received their bachelor's degree from a college/university other than LSU. ${ }^{35}$

To investigate whether judges with bachelors' degrees from LSU are driving all the rest of results, we re-estimated the models presented in Table 7. Recall that the regressions of Table 7 have analyzed the impact of an unexpected loss on sentence lengths by the importance of the football game, by offense type, and by defendant race. We added to these models an interaction term between LSU game results and a dummy variable that indicates if the judge has received his/her undergraduate degree from LSU. The results are displayed in Table 9. Column (1) presents the analysis of judicial decisions following a game when LSU football team was ranked in the top-10 going into the game. The coefficient of the upset loss, reported in the first row, is about 45 but it is not statistically different from zero. On the other hand, if the judge has a bachelor's degree from LSU, the impact of an upset loss on disposition length is 86 days $(44.8+41.8)$, and as reported towards the bottom of the table, this effect is significantly different from zero at the 2-percent level. Column (2) of Table 9 shows that the effect of an upset loss is smaller in magnitude and less precisely estimated when LSU is ranked below top 10 . The impact is 57 days and significant at 11 percent for judges who have a bachelor's degree from LSU. Table 9 also shows that if the undergraduate degree of the judge is from LSU, an upset loss triggers an

\footnotetext{
${ }^{35}$ We also examined heterogeneity by the law school judges graduated from, but did not detect any significant discrepancy between the coefficient estimates for judges who graduated from LSU law school versus other law schools. This suggests students' exposure to the culture of LSU football during their undergraduate education is more impactful than during law school education. This is intuitive because the duration of the former is longer (four years) and undergraduates are younger and arguable more impressionable.
} 
increase in sentence lengths for blacks defendants (column 5) as well as for those who are charged with felony crimes (column 3). On the other hand, upset losses have no impact on disposition lengths if LSU is not the undergraduate alma mater of the judge. This regularity implies that judges who have received their undergraduate education from LSU, and were therefore exposed to the LSU football culture, have stronger emotional attachments to the team in comparison to other judges. Thus, it is plausible that an unexpected loss of the LSU football team triggers a stronger emotional reaction among this group of judges, which translates into harsher sentences handed down. ${ }^{36}$

Using the estimated parameters of the model, we calculate that the excess punishment of juvenile defendants in Louisiana associated with each upset loss of the LSU football is about 1,332 days, including time in custody and probation. ${ }^{37}$ For defendants convicted of a felony, total additional jail time (secure custody) is 149 extra days due to an upset loss. ${ }^{38}$

\subsection{Additional Estimates and the Threat of Selection Bias}

In addition to their effects on disposition length, emotional cues generated by unexpected wins and losses on college football games may also have an impact on juveniles' propensity to be incarcerated (disposition type). To shed light on this issue, we define an indicator variable that takes the value of one if the disposition set by the judge was to incarcerate (secure/non-secure

${ }^{36}$ Strong emotional ties to college teams that last a lifetime have been documented recently by Clotfelter (2015).

${ }^{37}$ We observe a weekly average of 56 dispositions following an upset loss, and that 18 of these are handled by judges who have received their bachelor's degrees from LSU. Multiplying the estimated effect from an upset loss using column (3) of Table 8 (74 days) with the number of dispositions yields a total of 1,332 days.

${ }^{38}$ Recall that 43 percent of all dispositions in our data are felony crimes. We observe that 18 percent of felony crimes receive dispositions in secure custody by judges who have a bachelor's degree from LSU. Using the average weekly dispositions of 56 as our benchmark, we multiply the number of felonies ending up as secure custody with the estimated effect from Column 3 of Table 9. 
custody) the youth. In this analysis, the outcome in Equation (1) is an indicator that takes the value of one for incarceration, and it is zero if the defendant is placed on probation. The results from this specification are provided in Table 10. The results reported in column (1) are based on the entire sample. The regression in column (2) employs the decisions made by judges who have received their undergraduate degrees from LSU, and column (3) reports the results of the regression which uses the sample based on judges whose alma mater is not LSU. ${ }^{39}$ None of the coefficient estimates in the table is statistically different from zero. ${ }^{40}$ Further examination of the effects of emotional shocks on the probability of incarceration by nature of the game (LSU being in the top-10 vs. below top 10), broad offense types (felony vs. non-felony) and juvenile's race do not alter this result. ${ }^{4142}$

So far, we have not addressed the potential bias in the coefficient estimates that may arise due to sample selection. Recall that, if the judge has dismissed the case, the case is not disposed; i.e., no sentence length is assigned. In this situation, the juvenile is treated as if he/she had no contact with the OJJ, and the case is not recorded in the OJJ system. Consequently, our data allow us to observe only those cases that are not dismissed by the judge (see Section 2 for details). This particular selection, which could have been implemented by judges, does not constitute a

39 The sum of the sample sizes in columns (2) and (3) is less than the sample size in column (1) because in some cases we could not identify the undergraduate institution of the judges. Running the regression based on the sample of 6,789 observations (column 2 plus column 3) did not alter the results.

${ }^{40}$ Our conclusions remain intact if we instead classify the incarceration dummy to only include securecustody.

${ }^{41}$ These results, which are not reported in the interest of space, are available upon request.

${ }^{42}$ Given that judges make decisions on two margins (disposition type and disposition length), it is inappropriate econometrically to divide the sample by disposition type and analyze whether the impact of an unexpected loss is different between types of disposition. Nevertheless, when we ran the models for those who were assigned to secure custody and for those who were placed on probation, we found that the point estimates of an unexpected loss were similar in both regressions, although imprecisely estimated in the former case because of the small sample size $(n=1,225)$. 
problem for our results to the extent that emotional cues from game outcomes impact the propensity of dismissal in the same direction as the severity of the sentence length. More specifically, if judges have a lower propensity to dismiss a case after an upset loss, this implies that borderline cases (e.g. those with weak evidence and probably involving petty offenses) will end up at the docket during the week following an upset loss, rather than being dismissed (Robinson 2000; Bowers and Robinson 2012). This, in turn, implies that, selection would generate a sample which would include "less-guilty" defendants who are brought to trial after an upset loss. Thus, the impact we identify could be an underestimate of the true effect of an upset loss. $^{43}$

\subsection{Robustness Checks}

We implemented several sensitivity checks to examine the validity of our results. First, as an alternative to our discrete parameterization in Equation (1), we included a cubic polynomial in the point spread and an interaction between the polynomial and indicator for LSU football team loss (Card and Dahl 2011). Figure 6 plots the estimated interaction effect over a range of spread along with the associated pointwise $90 \%$ confidence interval. The effect of a loss on disposition length set by the judges is decreasing in the spread, and it is only statistically significant for spread values roughly less than -5 . Second, keeping our discrete parameterization, we also experimented with different cutoff values (e.g., -3 and 3) to describe unexpected college football game outcomes. The results remained intact.

Third, we used a Poisson regression to estimate the cuing effects on disposition length. Our results from this alternative model specification are consistent with those reported throughout

\footnotetext{
${ }^{43}$ In the same manner, the impact we identify could be an underestimate (overestimate) of the true effect of a close loss (upset win).
} 
the paper. Specifically, an upset loss leads to a 6.2 percent increase $(7$ percent from our preferred specification in the last column of Table 4) in the disposition length and we do not observe any statistically significant impact from a close loss or an upset win (column 1, Table A1). Fourth, employing the logarithm of the disposition length as the dependent variable did not affect the findings (column 2, Table A1).

Fifth, it is conceivable that emotional turmoil generated by hurricanes Katrina and Rita might have impacted the judicial decisions and game outcomes simultaneously. To address this concern we dropped all games played in the 2005 and 2006 football seasons. Doing so had almost no impact on our estimated effects (column 3, Table A1). Similarly, excluding bowl games from the sample or including very serious felonies (first and second degree murder and aggravated rape) produced virtually identical results (columns 4 and 5 , Table A1).

Sixth, as mentioned earlier, we limit our attention to first-time delinquents because repeat offenders are assigned to the same judge who presided over the case of the defendant in previous conviction. Dropping this restriction and including offenders with criminal history into the sample does not alter the results (column 6, Table A1). Seventh, we also dropped season-weeks where the total number of dispositions is more than the $90^{\text {th }}$ percentile of the number of weekly disposition distribution. This exercise minimizes any concerns regarding congestion of the docket; but doing so has no effect on the results (column 7, Table A1).

Eighth, to examine whether our results are driven by the decisions of a particular judge, we estimated Equation (1) repeatedly, each time removing dispositions set by a different judge. In a total of 207 regressions, the effect of an upset loss on disposition length was always statistically significant, whereas the coefficient estimates for the impact of a close loss or an upset win were never different from zero. The distribution of these 207 estimated coefficients were tight with a 
mean of 34.8 and standard deviation of 0.98 , indicating that the results are not driven by the behavior of a few judges.

Ninth, note that the results reported in the paper are based on the sample that excluded judicial decisions which took place during the weeks in which LSU had not played a game. Treating these weeks (bye weeks) as the omitted category in Equation (1) and adding full set of interactions between ex-ante classification of games and outcomes of games yield similar results (Table A2). Recall that we excluded one percent of the case files from the analysis where the sentence lengths were extraordinarily long as these could be data entry errors. Adding these observations to the sample did not change the results. Similarly, dropping the shortest one percent of disposition lengths did not alter the results either. And finally, dropping the defendants residing out of state ( 2 percent of the sample) generated almost identical results.

\subsection{Falsification Tests}

We performed two falsification tests. First, we replaced the LSU pregame point spread $\left(S_{k-1 s}\right)$ and the game outcome $\left(y_{k-1 s}\right)$ records with those of several other prominent college football Division I-A teams, and re-estimated the specification depicted by Equation (1) using these placebo values. Although these games were played during the same time period as the LSU games (1996-2012 football seasons), upset wins or upset losses of these other teams should trigger no emotional response from judges. To avoid any emotional spillover effects, we did not choose teams that are direct competitors of LSU (i.e., we did not focus on Southeastern Conference teams or teams from the neighboring states). Instead, we focused on three teams with national championship titles over the sample period (Florida State, Miami-Florida, and Ohio State), and two other teams from different subdivisions with successful histories (Brigham Young 
and Stanford). The results, displayed in Table 11, show that upset losses of Brigham Young, Florida State, Miami-Florida, Ohio State or Stanford have no impact on the decisions handed down by judges in Louisiana. ${ }^{44}$ The point estimates are either close to zero in magnitude or are of the opposite sign of theoretical expectations. In summary, the results of Table 11 indicate that, consistent with our expectations, college football results, obtained by other prominent teams have no impact on judges' decisions in Louisiana.

Second, we investigated whether judicial decisions in a given week are impacted by the game results of the following week. We estimated this specification using the weeks in which LSU football team has played games in consecutive weekends. The results are provided in Table 12. Column (1) replicates our benchmark regression (column 5, Table 4), but it is estimated using the sample based on games played in consecutive weeks. Column (2) of Table 12 reports the model where the disposition length assigned by judges is explained by the spread and game outcomes pertaining to the following week's game. All point estimates are small in magnitude and none of them is different from zero. Finally, in Column (3) we include both the information about the game played in the immediately preceding Saturday and the following Saturday. The results show that an upset loss has an impact on dispositions imposed by judges during the week following the game, but that the result of the following week's game has no impact.

\section{Summary and Discussion}

In this paper we utilize the universe of juvenile court decisions in the state of Louisiana between 1996 and 2012 to investigate the effects of emotional shocks associated with unexpected outcomes of football games played by Louisiana State University (LSU) football team on judicial

\footnotetext{
${ }^{44} \mathrm{We}$ employed a number of other teams as well. In no case were the results different from those reported in Table 11.
} 
decisions of juvenile court judges. We employ the Las Vegas bookmakers' pregame point spread to determine fans' (judges) rational expectations about the outcome of the game, and analyze the impact of unexpected game results on judicial decisions. Our ability to employ detailed microlevel data allows us to make inference on the disparity in sentencing based on observable juvenile and judge characteristics.

Using these naturally-occurring data which involve high-stake decisions, we analyze the behavior of judges. We show that upset losses of the LSU football team increase disposition (sentence) length imposed by judges, and that this effect persists throughout the work week following a Saturday game. On the other hand, losses of games that were expected to be close contests ex-ante, as well as upset wins have no impact. We also find that judges' reaction, triggered by an upset loss, is more pronounced after more important games (when LSU was ranked in top-10).

Different falsification tests and a variety of auxiliary analyses demonstrate the robustness of the results. We also provide evidence indicating that the results cannot be explained by attorney interference, defendant socio-economic background, or by potential courtroom misconduct of juveniles that could have prompted judges' anger.

The reaction of judges to an upset football loss cannot be attributed to decision fatigue of judges because the impact of an upset loss lasts for one work-week. They are, however, consistent with the hypothesis that emotional stress of judges is responsible for this outcome. It has been documented that emotions in one domain influence emotions, judgments and decisions in a completely unrelated domain (e.g. Edmans et al. 2007; Healy et al. 2010; Bodenhausen et al. 1994). Our results indicate that emotional stress is responsible for this reaction of judges because we find that the entire set of results are driven by judges who have received their bachelor's 
degrees from LSU.

We calculate that each upset loss of the LSU football team generates excess punishments of juvenile defenders in Louisiana by a total of more than 1,332 days, including time in custody and probation. Importantly, 159 extra days of jail time has been assigned to juveniles convicted of a felony due to an upset loss in a football game.

From a broader perspective, these results contribute to the investigation of unequal treatment of defendants in the judicial process. Differential treatment of minorities could emerge because of preferences, political reasons, in-group bias, or other systemic factors (Argus and Mocan 2004; Shayo and Zussman 2011; Abrams et al. 2012; Alesina and La Ferrara 2015; Grossman et al. 2016). In this paper, we show that emotional stress, imposed on judges externally, prompts them to impose harsher sentences on defendants who were unlucky enough to face the judge during the period of the stress. Furthermore, although the average sentence lengths (conditional on case, defendant and judge attributes) do not differ by defendant race in the absence of a football effect, it appears that an upset LSU football game loss increases the disposition length (sentence severity) of black defendants more severely in comparison to white defendants. Thus, the burden of the emotional trauma generated by the upset loss seems to fall on black defendants.

Our results also contribute to a growing body of literature that aims to find ways to test the impact of emotions on behavior in settings outside of the laboratory environments. In addition to its large sample size (the universe of juvenile court cases over a period of 16 years) and the detail of the data it employs, our paper has two other distinguishing aspects. First, it investigates the impact of an emotional shock among a group of decision-makers (judges) who are uniformly highly educated. Second, the decisions analyzed in the paper are made within the constraints of a 
legal framework which should minimize the extent of capricious judgments. Although legal realists have long argued that judges' decisions may be influenced by extraneous factors, highstake decisions about punishment severity are nevertheless expected to be free of person-specific reference points. ${ }^{45}$ Thus, it is noteworthy that the judicial decisions are in fact impacted by emotions that are unrelated to the merits of the case.

\footnotetext{
${ }^{45}$ For example, leading legal realist Judge Jerome Frank, who served as the Chairman of the Securities and Exchange Commission and a judge on the U.S. Court of Appeals for the Second Circuit, has famously argued that a judge's decision may be impacted by mundane things, including what he/she ate for breakfast.
} 


\section{References}

Abrams, D., M. Bertrand, and S. Mullainathan (2012). Do Judges Vary in Their Treatment of Race? Journal of Legal Studies 41 (2), 347-383.

Aizer, A. and J. J. Doyle (2015). Juvenile Incarceration, Human Capital and Future Crime: Evidence from Randomly-Assigned Judges. Quarterly Journal of Economics forthcoming.

Alesina, A. and E. La Ferrara (2014). A Test of Racial Bias in Capital Sentencing. American Economic Review 104 (11), 3397-3433.

Argys, L. M. and N. H. Mocan (2004). Who Shall Live and Who Shall Die? An Analysis of Prisoners on Death Row in the United States. Journal of Legal Studies 33 (2) 255-282.

Bodenhausen, G, L. Sheppard, and G. Kramer. (1994). Negative Affect and Social Judgment: The Differential Impact of Anger and Sadness. European Journal of Social Psychology 24 (1), 45-62.

Bowers, J. and P. H. Robinson (2012). Perceptions of Fairness and Justice: The Shared Aims and Occasional Conflicts of Legitimacy and Moral Credibility. Wake Forest Law Review 47 (2), 211284.

Card, D. and G. B. Dahl (2011). Family Violence and Football: The Effect of Unexpected Emotional Cues on Violent Behavior. Quarterly Journal of Economics 126 (1), 103-143.

Chen, D., T. Moskowitz, and K. Shue (2015). Decision-Making under the Gambler's Fallacy: Evidence from Asylum Judges, Loan Officers, and Baseball Umpires. Working Paper.

Chen, D. and H. Spamann (2014). This Morning's Breakfast, Last Night's Game: Detecting Extraneous Influences on Judging. Working Paper.

Clotfelter, C. (2015). Die-Hard Fans and the Ivory Tower's Ties that Bind. Social Science Quarterly 96 (2), 381-399.

Danziger, S., J. Levav, and L. Avnaim-Pesso (2011a). Extraneous Factors in Judicial Decisions. Proceedings of the National Academy of Sciences of the United States of America 108 (17), 6889-6892.

Danziger, S., J. Levav, and L. Avnaim-Pesso (2011b). Reply to Weinshall-Margel and Shapard: Extraneous Factors in Judicial Decisions Persist. Proceedings of the National Academy of Sciences of the United States of America 108 (42), E834. 
Edmans, A., D. Garcia, and Ø. Norli (2007). Sports Sentiment and Stock Returns. Journal of Finance 62 (4), 1967-1998.

Feinswog, L. (2013). Tales from the LSU Tiger Sideline: A Collection of Greatest Tiger Stories Ever Told. Sports Publishing.

Forgas, Joseph. (1995) Mood and Judgment. The Affect Infusion Model (AIM). Psychological Bulletin. 117(1), 39-66.

Grossman, G., O. Gazal-Ayal, S. Pimentel, and J. Weinstein (2016). Descriptive Representation and Judicial Outcomes in Multiethnic Societies. American Journal of Political Science 60 (1), 4469.

Healy, A., N. Malhotra, and C. H. Mo (2010). Irrelevant Events affect Voters' Evaluations of Government Performance. Proceedings of the National Academy of Sciences 107 (29), 1280412809.

Hockenberry, S. and C. Puzzanchera (2014). Juvenile Court Statistics. National Center for Juvenile Justice.

Hirshleifer, D. and T. Shumway. (2003). Good Day Sunshine: Stock Returns and the Weather. Journal of Finance 58 (3), 1009-1032.

Hunt, K. A., T. Bristol, and E. R. Bashaw (1999). A Conceptual Approach to Classifying Sports Fans. Journal of Services Marketing 13 (6), 439-452.

Kahneman, D. and A. Tversky (1979). Prospect Theory: An Analysis of Decision under Risk. Econometrica 47 (2), 263-292.

Kamstra, M., L. Kramer, and M. Levi (2003). Winter Blues: A SAD Stock Market Cycle. American Economic Review 93 (1), 324-343.

Keltner, D., P. C. Ellsworth, and K. Edwards (1993). Beyond simple Pessimism: Effects of Sadness and Anger on Social Perception. Journal of Personality and Social Psychology 64 (5), $740-752$.

Koszegi, B. and M. Rabin (2006). A Model of Reference-Dependent Preferences. Quarterly Journal of Economics 121 (4), 1133-1165. 
Landy, J. F. and G. P. Goodwin (2015). Does Incidental Disgust Amplify Moral Judgment? A Meta-Analytic Review of Experimental Evidence. Perspectives on Psychological Science 10 (4), 518-536.

Lerner, J., Y. Li, P. Valdesolo, and K. Kassam. (2015). Emotion and Decision Making. Annual Review of Psychology 66. 799-823.

Lim, C. S. H., J. M. Snyder Jr., and D. Strömberg (2015). The Judge, the Politician, and the Press: Newspaper Coverage and Criminal Sentencing across Electoral Systems. American Economic Journal: Applied Economics 7 (4), 103-135.

Linder, J. A., J. Doctor, M. Friedberg, H. R. Nieva, C. Birks, D. Meeker, and C. Fox (2014). Time of Day and the Decision to Prescribe Antibiotics. JAMA International Medicine 174 (12), 20292013.

Lindo, J., I. Swensen, and G. Waddell (2012). Are Big-time Sports a Threat to Student Achievement? American Economic Journal: Applied Economics 4 (4), 254-274.

Louisiana Children's Code (1996-2012). Louisiana State Legislature-Various Chapters.

Louisiana District Judges Association Periodicals (1956-2000). Guide to the Louisiana Judiciary.

Miller, T. Q., L. Heath, J. R. Molcan, and B. L. Dugoni (1991). Imitative Violence in the Real World: A Reanalysis of Homicide Rates Following Championship Prize Fights. Aggressive Behavior 17 (3), 121-134.

National Football Foundation (2013). Passion for College Football Remains Robust.

Philippe, A. and A. Ouss (2015). "No Hatred or Malice, Fear or Affection": Media and Sentencing. Working Paper.

Phillips, D. P. (1983). The Impact of Mass Media Violence on U.S. Homicides. American Sociological Review 48 (4), 560-568.

Quigley, B. and J. Tedeshi. (1996). Mediating Effects of Blame Attributes on Feelings of Anger. Personality and Social Psychology Bulletin 22 (12), 1280-1288.

Rabin, M. and D. Vayanos (2010). The Gambler's and Hot-hand Fallacies: Theory and Applications. Review of Economic Studies 77 (2), 730-778. 
Robinson, P. H. (2000). Why Does the Criminal Law Care What the Lay Person Thinks Is Just? Coercive versus Normative Crime Control. Virginia Law Review 86 (8), 1838-1869.

Schnall, S., J. Haidt, G. Clore, and A. Jordan (2008). Disguts as Embodied Moral Judgment. Personality and Social Psychology Bulletin 34 (8), 1096-1109.

Schwarz, Norbert and Gerald Clore. (1983). Mood, Misattribution, and Judgments of Well-being: Informative and Directive Functions of Affective States. Journal of Personality and Social Psychology. 45 (3), 513-523.

Shayo, M. and A. Zussman (2011). Judicial Ingroup Bias in the Shadow of Terrorism. Quarterly Journal of Economics 126 (3), 1447-1484.

Tversky, A. and D. Kahneman (1974). Judgment under Uncertainty: Heuristics and Biases. Science 185 (4157), 1124-1131.

Weinshall-Margel K. and J. Shapard (2011). Overlooked Factors in the Analysis of Parole Decisions. Proceedings of the National Academy of Sciences of the United States of America 108 (42), E833. 
Table 1

Summary Statistics for Juveniles and Judges

\begin{tabular}{lcc}
\hline \hline & Mean & SD \\
\hline Panel A: Juvenile Characteristics & & \\
Disposition Length & 512.639 & 338.679 \\
Incarceration (Secure and Non-secure Custody) & 0.264 & 0.441 \\
Black & 0.623 & 0.484 \\
White & 0.356 & 0.478 \\
Female & 0.236 & 0.424 \\
Age & 14.767 & 1.501 \\
Committed a Felony & 0.419 & 0.493 \\
Sample Size & 8,228 & \\
Panel B: Judge Characteristics & & \\
Black & 0.115 & 0.320 \\
White & 0.885 & 0.320 \\
Female & 0.227 & 0.419 \\
Age & 56.111 & 9.470 \\
Party Affiliation-Democratic Party & 0.727 & 0.444 \\
College Degree from LSU & 0.327 & 0.470 \\
LSU Law School & 0.473 & 0.500 \\
Number of Judges & 207 & \\
\hline \hline
\end{tabular}

The statistics above reflect our research sample, which consists of juveniles who were disposed before the judge the week following a Saturday LSU football game during the seasons from 1996 to 2012, as well as their corresponding disposition judges. The variables are only a subset of those used in the analysis. The descriptive statistics of the 171 individual offense categories are not reported. There are 180 judges with non-missing information on their alma mater. 
Table 2

LSU Football Games Win-Loss Record for the Seasons from 1996 to 2012

\begin{tabular}{|c|c|c|c|c|c|c|c|c|c|}
\hline & \multicolumn{9}{|c|}{ Seasons } \\
\hline & 1996 & 1997 & 1998 & 1999 & 2000 & 2001 & 2002 & 2003 & 2004 \\
\hline $\begin{array}{l}\text { LSU Season } \\
\text { Record (Win-Loss) }\end{array}$ & $10-2$ & $9-3$ & $4-7$ & $3-8$ & $8-4$ & $10-3$ & $8-5$ & $13-1$ & $9-3$ \\
\hline & 2005 & 2006 & 2007 & 2008 & 2009 & 2010 & 2011 & 2012 & \\
\hline $\begin{array}{l}\text { LSU Season } \\
\text { Record (Win-Loss) }\end{array}$ & $11-2$ & $11-2$ & $12-2$ & $8-5$ & $9-4$ & $11-2$ & $13-1$ & $10-3$ & \\
\hline
\end{tabular}

Win-Loss records include all season games and bowl and championship games from 1996 to 2012. 
Table 3

Summary Statistics for LSU Football Games for Seasons from 1996 to 2012

\section{Number of Games \\ Percent of} [Number of Dispositions]

Category

\section{Panel A: All LSU Football Games}

Football Games on Saturday*

179

84.8

Football Games on Other Days

15.2

Panel B: Saturday Games

Outcome

Win

Loss

Predicted Outcomes

Predicted Win: point spread -4 or less

Predicted Close: $-4<$ point spread $<4$

Predicted Loss: point spread 4 or more

Actual Outcomes

Actual Loss (Upset Loss)

[781]

Actual Loss (Close Loss)

[612]

[552]
14

14

10

[18.8]

11.5

[46.1]

35.7

[35.5]

86

48.0

Football Games when LSU was ranked in Top 10

Win-Loss records include all regular season games and bowl and the championship games from 1996 to 2012. Associated Press ranking lists the top 25 college football teams, and it is published every Sunday during the college football season. See text for further details. $\quad(*)$ There are 7 post-season bowl games played on Saturdays during this period. 
Table 4

The Effect of Emotional Shocks from LSU Football Games on Disposition Length Imposed by Judges

\begin{tabular}{|c|c|c|c|c|c|}
\hline & \multicolumn{5}{|c|}{ Dependent Variable: Disposition Length } \\
\hline & $(1)$ & $(2)$ & $(3)$ & $(4)$ & $(5)$ \\
\hline Loss $\times$ Predicted Win (Upset Loss) & $\begin{array}{c}37.494 * * \\
(18.840)\end{array}$ & $\begin{array}{c}39.815^{* *} \\
(18.902)\end{array}$ & $\begin{array}{c}40.559 * * \\
(18.548)\end{array}$ & $\begin{array}{c}40.971 * * \\
(18.368)\end{array}$ & $\begin{array}{c}34.798 * * \\
(13.848)\end{array}$ \\
\hline Loss $\times$ Predicted Close (Close Loss) & $\begin{array}{c}24.225 \\
(20.242)\end{array}$ & $\begin{array}{c}20.383 \\
(20.036)\end{array}$ & $\begin{array}{c}21.081 \\
(19.324)\end{array}$ & $\begin{array}{c}21.439 \\
(19.356)\end{array}$ & $\begin{array}{c}3.708 \\
(17.915)\end{array}$ \\
\hline Win $\times$ Predicted Loss (Upset Win) & $\begin{array}{l}-15.490 \\
(27.507)\end{array}$ & $\begin{array}{l}-17.488 \\
(27.416)\end{array}$ & $\begin{array}{l}-11.809 \\
(27.003)\end{array}$ & $\begin{array}{l}-10.878 \\
(26.738)\end{array}$ & $\begin{array}{l}-10.548 \\
(21.329)\end{array}$ \\
\hline Predicted Close & $\begin{array}{c}-1.177 \\
(17.922)\end{array}$ & $\begin{array}{c}0.616 \\
(17.516)\end{array}$ & $\begin{array}{c}-4.612 \\
(17.458)\end{array}$ & $\begin{array}{c}-5.877 \\
(17.575)\end{array}$ & $\begin{array}{c}-7.832 \\
(13.178)\end{array}$ \\
\hline Predicted Loss & $\begin{array}{c}20.701 \\
(18.282)\end{array}$ & $\begin{array}{c}22.485 \\
(18.166)\end{array}$ & $\begin{array}{c}21.123 \\
(18.063)\end{array}$ & $\begin{array}{c}19.398 \\
(18.859)\end{array}$ & $\begin{array}{c}4.902 \\
(14.413)\end{array}$ \\
\hline Sample Size & 8,288 & 8,288 & 8,288 & 8,288 & 8,288 \\
\hline Controls: & & & & & \\
\hline Season, Week, and Days of Week & Yes & Yes & Yes & Yes & Yes \\
\hline Judge Attributes & No & Yes & Yes & Yes & No \\
\hline Juvenile Attributes & No & No & Yes & Yes & Yes \\
\hline Game Attributes & No & No & No & Yes & Yes \\
\hline Offense Fixed Effects & No & No & No & No & Yes \\
\hline Judge Fixed Effects & No & No & No & No & Yes \\
\hline
\end{tabular}

The sample is restricted to all juvenile dispositions following a Saturday football game during the seasons from 1996 to 2012 . Predicted Win indicates a point spread of -4 or less, Predicted Close indicates a point spread between -4 and 4 (exclusive), and Predicted Loss stands for a point spread of 4 or more. Standard errors, which are clustered at the judge level, are reported in parentheses. Judge controls include indicators for judge's gender, race and political party affiliation as well as judge's age and its square. Juvenile controls include indicators for juvenile's gender and race as well as age and its square. The game controls include indicators for home and bowl games. There are 171 detailed offense types and 207 judges in the effective sample. Judge fixed effect specification include time varying characteristics (indicator for party affiliation, age and its square). Predicted Win is the omitted category. *significant at $10 \%, * *$ significant at $5 \%, * * *$ significant at $1 \%$. 


\section{Table 5}

The Effect of Emotional Shocks from LSU Football Games on Disposition Length Imposed by Judges: Differential Impact of Early Weekday Decisions

\begin{tabular}{|c|c|c|}
\hline \multirow[t]{2}{*}{$\begin{array}{l}\text { Dependent Variable: } \\
\text { Disposition Length }\end{array}$} & $\begin{array}{l}\text { Early Week } \\
=\{\text { Mon. }\}\end{array}$ & $\begin{array}{c}\text { Early Week= } \\
\text { \{Mon., Tu., Wed.\} }\end{array}$ \\
\hline & $(1)$ & $(2)$ \\
\hline \multirow[t]{2}{*}{ Loss $\times$ Predicted Win (Upset Loss) } & $37.141 * *$ & 32.084 \\
\hline & $(15.206)$ & $(21.569)$ \\
\hline \multirow[t]{2}{*}{ Loss $\times$ Predicted Win $\times$ Early Week Days } & -14.546 & 3.980 \\
\hline & $(30.405)$ & $(22.809)$ \\
\hline \multirow[t]{2}{*}{ Loss $\times$ Predicted Close (Close Loss) } & 2.550 & 5.687 \\
\hline & $(18.781)$ & $(27.640)$ \\
\hline \multirow{2}{*}{ Loss $\times$ Predicted Close $\times$ Early Week Days } & 9.067 & -2.979 \\
\hline & $(31.905)$ & $(32.219)$ \\
\hline \multirow[t]{2}{*}{ Win $\times$ Predicted Loss (Upset Win) } & -13.487 & -19.127 \\
\hline & $(22.255)$ & $(28.129)$ \\
\hline \multirow{2}{*}{ Win $\times$ Predicted Loss $\times$ Early Week Days } & 23.448 & 14.623 \\
\hline & $(45.772)$ & $(36.396)$ \\
\hline \multirow[t]{2}{*}{ Predicted Close } & -7.842 & -7.993 \\
\hline & $(13.182)$ & $(13.141)$ \\
\hline \multirow[t]{2}{*}{ Predicted Loss } & 4.960 & 4.794 \\
\hline & $(14.418)$ & $(14.489)$ \\
\hline Sample Size & 8,228 & 8,228 \\
\hline \multicolumn{3}{|l|}{ Controls: } \\
\hline Season, Week, and Days of Week & Yes & Yes \\
\hline Judge Attributes & No & No \\
\hline Juvenile Attributes & Yes & Yes \\
\hline Game Attributes & Yes & Yes \\
\hline Offense Fixed Effects & Yes & Yes \\
\hline Judge Fixed Effects & Yes & Yes \\
\hline
\end{tabular}

Standard errors, which are clustered at the judge level, are reported in parentheses. Early Weekday indicator in column (1) includes only Monday, while it includes Monday through Wednesday in column (2). See notes to Table 4 and the text for data and control variable details. *significant at $10 \%, * *$ significant at $5 \%, * * *$ significant at $1 \%$. 
Table 6

The Long-Run Effect of Emotional Shocks from LSU Football Games on Disposition Length Imposed by Judges

\begin{tabular}{|c|c|c|c|}
\hline Dependent Variable: Disposition Length & (1) & (2) & (3) \\
\hline Loss $\times$ Predicted Win (Upset Loss) & $\begin{array}{l}31.488 * * \\
(14.994)\end{array}$ & ..... & $\begin{array}{c}30.861 * * \\
(15.054)\end{array}$ \\
\hline Loss $\times$ Predicted Close (Close Loss) & $\begin{array}{c}18.074 \\
(20.190)\end{array}$ & $\cdots \cdots$ & $\begin{array}{c}23.030 \\
(19.020)\end{array}$ \\
\hline Win $\times$ Predicted Loss (Upset Win) & $\begin{array}{l}-16.074 \\
(25.042)\end{array}$ & $\cdots \cdots$ & $\begin{array}{l}-26.716 \\
(26.816)\end{array}$ \\
\hline Predicted Close & $\begin{array}{l}-26.479 \\
(19.771)\end{array}$ & $\cdots \cdots$ & $\begin{array}{l}-35.062 * \\
(19.547)\end{array}$ \\
\hline Predicted Loss & $\begin{array}{c}15.468 \\
(18.826)\end{array}$ & $\ldots$. & $\begin{array}{c}14.073 \\
(18.801)\end{array}$ \\
\hline Loss $\times$ Predicted Win (Upset Loss)-Week Before & $\ldots .$. & $\begin{array}{c}-3.709 \\
(22.452)\end{array}$ & $\begin{array}{c}-1.848 \\
(23.378)\end{array}$ \\
\hline Loss $\times$ Predicted Close (Close Loss)-Week Before & $\ldots$. & $\begin{array}{c}-0.718 \\
(32.001)\end{array}$ & $\begin{array}{c}3.953 \\
(31.113)\end{array}$ \\
\hline Win $\times$ Predicted Loss (Upset Win)-Week Before & ..... & $\begin{array}{c}0.531 \\
(25.366)\end{array}$ & $\begin{array}{c}-2.346 \\
(25.579)\end{array}$ \\
\hline Predicted Close-Week Before & ..... & $\begin{array}{c}3.875 \\
(22.472)\end{array}$ & $\begin{array}{c}1.065 \\
(22.275)\end{array}$ \\
\hline Predicted Loss-Week Before & $\ldots$. & $\begin{array}{c}-21.526 \\
(18.980) \\
\end{array}$ & $\begin{array}{c}-27.962 \\
(19.018) \\
\end{array}$ \\
\hline Sample Size & 5,896 & 5,896 & 5,896 \\
\hline \multicolumn{4}{|c|}{$\begin{array}{l}\text { The sample is restricted to all juvenile dispositions following Saturday games played in consecutive weeks during } \\
\text { the seasons from } 1996 \text { to } 2012 \text {. Standard errors, which are clustered at the judge level, are reported in parentheses } \\
\text { All specifications control for day of the week, week and season effects, (time-variant) judge, juvenile } \\
\text { characteristics and offense and judge fixed effects. There are } 156 \text { detailed offense types and } 205 \text { judges in the } \\
\text { effective sample. See notes to Table } 4 \text { and the text for data and control variable details. *significant at } 10 \%, * * \\
\text { significant at } 5 \%, * * * \text { significant at } 1 \% \text {. }\end{array}$} \\
\hline
\end{tabular}


Table 7

The Effect of Emotional Shocks from LSU Football Games on Disposition Length Imposed by Judges: by Type of Game, Type of Crime, and the Race of the Juvenile

\begin{tabular}{|c|c|c|c|c|c|c|}
\hline \multirow{3}{*}{$\begin{array}{l}\text { Dependent Variable: } \\
\text { Disposition Length }\end{array}$} & \multicolumn{2}{|c|}{ Game Type } & \multicolumn{2}{|c|}{ Offense Type } & \multicolumn{2}{|c|}{ Juvenile Race } \\
\hline & $\begin{array}{c}\text { LSU Ranks } \\
\text { in Top } 10\end{array}$ & $\begin{array}{c}\text { LSU Ranks } \\
\text { Below Top } 10\end{array}$ & Felony & Non-Felony & Black & White \\
\hline & $(1)$ & $(2)$ & $(3)$ & $(4)$ & $(5)$ & $(6)$ \\
\hline Loss $\times$ Predicted Win (Upset Loss) & $\begin{array}{c}62.823 * * * \\
(22.704)\end{array}$ & $\begin{array}{c}36.244 \\
(26.622)\end{array}$ & $\begin{array}{c}34.421 \\
(21.834)\end{array}$ & $\begin{array}{l}30.734^{*} \\
(17.420)\end{array}$ & $\begin{array}{c}46.053 * * * \\
(15.459)\end{array}$ & $\begin{array}{c}8.308 \\
(23.098)\end{array}$ \\
\hline Loss $\times$ Predicted Close (Close Loss) & $\begin{array}{c}26.201 \\
(34.402)\end{array}$ & $\begin{array}{c}2.667 \\
(30.009)\end{array}$ & $\begin{array}{c}10.103 \\
(38.631)\end{array}$ & $\begin{array}{c}13.465 \\
(22.335)\end{array}$ & $\begin{array}{c}3.007 \\
(23.099)\end{array}$ & $\begin{array}{c}11.159 \\
(35.637)\end{array}$ \\
\hline Win $\times$ Predicted Loss (Upset Win) & $\begin{array}{c}45.913 \\
(62.649)\end{array}$ & $\begin{array}{l}-24.810 \\
(24.541)\end{array}$ & $\begin{array}{l}-38.242 \\
(40.143)\end{array}$ & $\begin{array}{c}7.075 \\
(23.330)\end{array}$ & $\begin{array}{c}-5.491 \\
(28.259)\end{array}$ & $\begin{array}{c}-0.478 \\
(32.209)\end{array}$ \\
\hline Predicted Close & $\begin{array}{c}-9.847 \\
(17.282)\end{array}$ & $\begin{array}{l}-10.144 \\
(21.965)\end{array}$ & $\begin{array}{l}-10.726 \\
(25.487)\end{array}$ & $\begin{array}{l}-11.885 \\
(15.132)\end{array}$ & $\begin{array}{l}-18.477 \\
(20.000)\end{array}$ & $\begin{array}{c}5.767 \\
(24.056)\end{array}$ \\
\hline Predicted Loss & $\begin{array}{l}-40.371 \\
(31.129)\end{array}$ & $\begin{array}{l}21.358 \\
(24.181)\end{array}$ & $\begin{array}{c}1.041 \\
(28.669)\end{array}$ & $\begin{array}{c}9.516 \\
(16.970)\end{array}$ & $\begin{array}{c}-3.256 \\
(22.457)\end{array}$ & $\begin{array}{l}27.220 \\
(22.345)\end{array}$ \\
\hline Average Disposition Length & 476.286 & 539.256 & 636.340 & 423.096 & 519.294 & 500.844 \\
\hline Sample Size & 3,478 & 4,750 & 3,455 & 4,773 & 5,132 & 2,932 \\
\hline Controls: & & & & & & \\
\hline Season, Week, and Days of Week & Yes & Yes & Yes & Yes & Yes & Yes \\
\hline Judge Attributes & No & No & No & No & No & No \\
\hline Juvenile Attributes & Yes & Yes & Yes & Yes & Yes & Yes \\
\hline Game Attributes & Yes & Yes & Yes & Yes & Yes & Yes \\
\hline Offense Fixed Effects & Yes & Yes & Yes & Yes & Yes & Yes \\
\hline Judge Fixed Effects & Yes & Yes & Yes & Yes & Yes & Yes \\
\hline
\end{tabular}

Standard errors, which are clustered at the judge level, are reported in parentheses. Offense classifications (felony and non-felony) are based on the Louisiana Office of Juvenile Justice categorization. See notes to Table 4 and the text for data and control variable details. The p-value pertains to the null hypothesis that the coefficients on upset loss are equal to each other across relevant subgroups. *significant at $10 \%$, ** significant at $5 \%$, *** significant at $1 \%$. 
Table 8

The Effect of Emotional Shocks from LSU Football Games on Disposition Length Imposed by Judges: by Differences in Adjudication and Disposition Dates, and by Judges' Alma Mater

\begin{tabular}{|c|c|c|c|c|}
\hline \multirow[t]{2}{*}{$\begin{array}{l}\text { Dependent Variable: } \\
\text { Disposition Length }\end{array}$} & $\begin{array}{c}\text { Adjudication and } \\
\text { Disposition Dates in } \\
\text { the Same Week }\end{array}$ & $\begin{array}{c}\text { Adjudication and } \\
\text { Disposition Dates At } \\
\text { Least One Week Apart }\end{array}$ & $\begin{array}{l}\text { Judges with } \\
\text { Bachelor's } \\
\text { Degree from } \\
\text { LSU }\end{array}$ & $\begin{array}{c}\text { Judges with } \\
\text { Bachelor's } \\
\text { Degree from } \\
\text { Universities } \\
\text { other than LSU }\end{array}$ \\
\hline & $(1)$ & $(2)$ & $(3)$ & $(4)$ \\
\hline Loss $\times$ Predicted Win (Upset Loss) & $\begin{array}{l}35.619^{* *} \\
(15.314)\end{array}$ & $\begin{array}{c}47.485 \\
(48.622)\end{array}$ & $\begin{array}{l}74.157 * * \\
(28.234)\end{array}$ & $\begin{array}{c}11.608 \\
(18.228)\end{array}$ \\
\hline Loss $\times$ Predicted Close (Close Loss) & $\begin{array}{c}9.158 \\
(20.699)\end{array}$ & $\begin{array}{c}10.611 \\
(41.770)\end{array}$ & $\begin{array}{c}5.833 \\
(36.548)\end{array}$ & $\begin{array}{c}32.162 \\
(22.291)\end{array}$ \\
\hline Win $\times$ Predicted Loss (Upset Win) & $\begin{array}{c}-5.173 \\
(21.997)\end{array}$ & $\begin{array}{l}-52.545 \\
(68.309)\end{array}$ & $\begin{array}{c}26.540 \\
(35.363)\end{array}$ & $\begin{array}{c}3.711 \\
(29.181)\end{array}$ \\
\hline Predicted Close & $\begin{array}{c}-6.356 \\
(14.792)\end{array}$ & $\begin{array}{l}-39.241 \\
(43.337)\end{array}$ & $\begin{array}{c}1.036 \\
(26.049)\end{array}$ & $\begin{array}{c}-34.035^{* *} \\
(16.941)\end{array}$ \\
\hline Predicted Loss & $\begin{array}{c}2.969 \\
(14.556)\end{array}$ & $\begin{array}{c}11.560 \\
(51.112)\end{array}$ & $\begin{array}{l}-28.103 \\
(28.661)\end{array}$ & $\begin{array}{c}15.569 \\
(16.146)\end{array}$ \\
\hline Average Disposition Length & 502.167 & 567.739 & 503.966 & 515.975 \\
\hline Sample Size & 6,914 & 1,314 & 2,106 & 4,683 \\
\hline Controls: & & & & \\
\hline Season, Week, and Days of Week & Yes & Yes & Yes & Yes \\
\hline Judge Attributes & No & No & No & No \\
\hline Juvenile Attributes & Yes & Yes & Yes & Yes \\
\hline Game Attributes & Yes & Yes & Yes & Yes \\
\hline Offense Fixed Effects & Yes & Yes & Yes & Yes \\
\hline Judge Fixed Effects & Yes & Yes & Yes & Yes \\
\hline
\end{tabular}

Standard errors, which are clustered at the judge level, are reported in parentheses. There are 180 judges with non-missing information on their alma mater (16 6 detailed offense types). 59 judges have received their undergraduate degree from LSU. See notes to Table 4 and the text for data and control variable details. The pvalue pertains to the null hypothesis that the coefficients on upset loss are equal to each other. *significant at $10 \%,{ }^{* *}$ significant at $5 \%$, $* * *$ significant at $1 \%$. 
Table 9

The Effect of Emotional Shocks from LSU Football Games on Disposition Length Imposed by Judges who have Received Their Bachelor's Degree from LSU: by Type of Game, Type of Crime, and the Race of the Juvenile

\begin{tabular}{|c|c|c|c|c|c|c|}
\hline \multirow{3}{*}{$\begin{array}{l}\text { Dependent Variable: } \\
\text { Disposition Length }\end{array}$} & \multicolumn{2}{|c|}{ Game Type } & \multicolumn{2}{|c|}{ Offense Type } & \multicolumn{2}{|c|}{ Juvenile Race } \\
\hline & $\begin{array}{l}\text { LSU Ranks in } \\
\text { Top } 10\end{array}$ & $\begin{array}{l}\text { LSU Ranks } \\
\text { Below Top } 10\end{array}$ & Felony & Non-Felony & Black & White \\
\hline & $(1)$ & $(2)$ & $(3)$ & (4) & $(5)$ & $(6)$ \\
\hline Loss $\times$ Predicted Win (Upset Loss) & $\begin{array}{c}44.792 \\
(29.745)\end{array}$ & $\begin{array}{c}-8.269 \\
(32.521)\end{array}$ & $\begin{array}{c}22.339 \\
(31.561)\end{array}$ & $\begin{array}{c}0.768 \\
(21.853)\end{array}$ & $\begin{array}{c}23.439 \\
(19.877)\end{array}$ & $\begin{array}{l}-27.874 \\
(28.399)\end{array}$ \\
\hline Loss $\times$ Predicted Win $\times$ Judge's Bachelor's Degree from LSU & $\begin{array}{c}41.812 \\
(40.323)\end{array}$ & $\begin{array}{c}64.590 \\
(39.931)\end{array}$ & $\begin{array}{c}79.768 \\
(46.368)\end{array}$ & $\begin{array}{c}32.159 \\
(33.948)\end{array}$ & $\begin{array}{c}53.080 \\
(33.485)\end{array}$ & $\begin{array}{c}77.020 \\
(49.358)\end{array}$ \\
\hline Loss $\times$ Predicted Close (Close Loss) & $\begin{array}{c}52.329 \\
(47.246)\end{array}$ & $\begin{array}{l}24.738 \\
(31.332)\end{array}$ & $\begin{array}{c}56.973 \\
(51.929)\end{array}$ & $\begin{array}{l}19.352 \\
(30.722)\end{array}$ & $\begin{array}{c}11.487 \\
(26.216)\end{array}$ & $\begin{array}{c}42.446 \\
(35.080)\end{array}$ \\
\hline Loss $\times$ Predicted Close $\times$ Judge's Bachelor's Degree from LSU & $\begin{array}{l}-43.870 \\
(45.908)\end{array}$ & $\begin{array}{c}31.146 \\
(52.644)\end{array}$ & $\begin{array}{l}-8.636 \\
(60.818)\end{array}$ & $\begin{array}{l}-37.046 \\
(42.365)\end{array}$ & $\begin{array}{c}7.485 \\
(47.350)\end{array}$ & $\begin{array}{c}-7.071 \\
(42.374)\end{array}$ \\
\hline Win $\times$ Predicted Loss (Upset Win) & $\begin{array}{c}15.304 \\
(100.837)\end{array}$ & $\begin{array}{c}-0.975 \\
(31.105)\end{array}$ & $\begin{array}{l}-40.617 \\
(49.397)\end{array}$ & $\begin{array}{c}38.450 \\
(28.920)\end{array}$ & $\begin{array}{c}15.649 \\
(35.663)\end{array}$ & $\begin{array}{c}2.228 \\
(40.207)\end{array}$ \\
\hline Win $\times$ Predicted Loss $\times$ Judge's Bachelor's Degree from LSU & $\begin{array}{c}23.869 \\
(117.580)\end{array}$ & $\begin{array}{c}-3.069 \\
(38.155)\end{array}$ & $\begin{array}{c}62.571 \\
(69.066)\end{array}$ & $\begin{array}{l}-52.238 \\
(35.104)\end{array}$ & $\begin{array}{l}-24.090 \\
(52.419)\end{array}$ & $\begin{array}{r}35.015 \\
(55.956)\end{array}$ \\
\hline Predicted Close & $\begin{array}{l}-14.221 \\
(19.012)\end{array}$ & $\begin{array}{l}-36.304 \\
(22.718)\end{array}$ & $\begin{array}{l}-33.691 \\
(28.504)\end{array}$ & $\begin{array}{l}-18.618 \\
(17.097)\end{array}$ & $\begin{array}{l}-41.387 \\
(21.106)\end{array}$ & $\begin{array}{r}10.250 \\
(28.723)\end{array}$ \\
\hline Predicted Loss & $\begin{array}{l}-35.626 \\
(34.791)\end{array}$ & $\begin{array}{c}-1.303 \\
(26.636)\end{array}$ & $\begin{array}{c}-0.136 \\
(35.010)\end{array}$ & $\begin{array}{c}-4.655 \\
(18.581)\end{array}$ & $\begin{array}{l}-14.052 \\
(24.567)\end{array}$ & $\begin{array}{l}25.533 \\
(25.407)\end{array}$ \\
\hline Average Disposition Length & 482.208 & 534.746 & 630.738 & 425.478 & 515.913 & 505.096 \\
\hline Sample Size & 2,907 & 3,882 & 2,870 & 3,919 & 4,204 & 2,452 \\
\hline $\begin{array}{l}\text { p-value (Upset Loss }+ \text { Upset Loss } \times \text { LSU Degree) } \\
\text { Controls: }\end{array}$ & 0.02 & 0.11 & 0.01 & 0.23 & 0.01 & 0.27 \\
\hline Season, Week, and Days of Week & Yes & Yes & Yes & Yes & Yes & Yes \\
\hline Judge Attributes & No & No & No & No & No & No \\
\hline Juvenile Attributes & Yes & Yes & Yes & Yes & Yes & Yes \\
\hline Game Attributes & Yes & Yes & Yes & Yes & Yes & Yes \\
\hline Offense Fixed Effects & Yes & Yes & Yes & Yes & Yes & Yes \\
\hline Judge Fixed Effects & Yes & Yes & Yes & Yes & Yes & Yes \\
\hline
\end{tabular}

Standard errors, which are clustered at the judge level, are reported in parentheses. Offense classifications (felony and non-felony) are based on the Louisiana Office of Juvenile Justice categorization. See notes to Tables 4 and 8 as well as the text for data and control variable details. The first p-value pertains to the null hypothesis that the sum of the coefficients in the first two rows is zero. The second p-value pertains to the null hypothesis that the coefficients on upset loss are equal to each other. * significant at $10 \%, * *$ significant at $5 \%, * * *$ significant at $1 \%$. 
Table 10

The Effect of Emotional Shocks from LSU Football Games on the Propensity for Incarceration

\begin{tabular}{lccc}
\hline \hline $\begin{array}{l}\text { Dependent Variable: Incarceration } \\
\text { (Secure and Non-Secure Custody) }\end{array}$ & Full Sample & $\begin{array}{c}\text { Judges with Bachelor's } \\
\text { Degree from LSU }\end{array}$ & $\begin{array}{c}\text { Judges with Bachelor's } \\
\text { Degree from Universities } \\
\text { other than LSU }\end{array}$ \\
\cline { 2 - 4 } & $(1)$ & $(2)$ & -0.011 \\
\hline Loss $\times$ Predicted Win (Upset Loss) & -0.002 & -0.023 & $(0.026)$ \\
Loss $\times$ Predicted Close (Close Loss) & $(0.018)$ & $(0.034)$ & 0.005 \\
& -0.016 & -0.008 & $(0.028)$ \\
Win $\times$ Predicted Loss (Upset Win) & $(0.023)$ & $(0.042)$ & -0.043 \\
& -0.020 & 0.050 & $(0.034)$ \\
Predicted Close & $(0.026)$ & $(0.051)$ & 0.008 \\
& 0.024 & 0.012 & $(0.023)$ \\
Predicted Loss & $(0.018)$ & $(0.037)$ & $0.057^{*}$ \\
& $0.041 * *$ & -0.000 & $(0.031)$ \\
Sample Size & $(0.020)$ & $(0.028)$ & 4,683 \\
Controls: & 8,228 & 2,106 & Yes \\
Season, Week, and Days of Week & & & No \\
Judge Attributes & Yes & Yes & Yes \\
Juvenile Attributes & No & No & Yes \\
Game Attributes & Yes & Yes & Yes \\
Offense Fixed Effects & Yes & Yes & Yes \\
Judge Fixed Effects & Yes & Yes & \\
\hline \hline
\end{tabular}

The dependent variable takes the value of one if the juvenile defendant was in incarcerated (received disposition in secure or non-secure custody) and zero if the defendant was put on probation. Standard errors, which are clustered at the judge level, are reported in parentheses. See notes to Tables 4 and 8 as well as the text for data and control variable details. * significant at $10 \%$, ** significant at $5 \%$, *** significant at $1 \%$. 
Table 11

Falsification Tests- The Effect of Emotional Shocks from Selected College Football Teams' Games on Disposition Length Imposed by Judges

\begin{tabular}{|c|c|c|c|c|c|}
\hline $\begin{array}{l}\text { Dependent Variable: } \\
\text { Disposition Length }\end{array}$ & $\begin{array}{c}\text { Brigham } \\
\text { Young } \\
\end{array}$ & $\begin{array}{c}\text { Florida } \\
\text { State } \\
\end{array}$ & $\begin{array}{l}\text { Miami- } \\
\text { Florida }\end{array}$ & Ohio State & Stanford \\
\hline & $(1)$ & $(2)$ & (3) & $(4)$ & $(5)$ \\
\hline Loss $\times$ Predicted Win (Upset Loss) & $\begin{array}{c}4.668 \\
(17.083)\end{array}$ & $\begin{array}{c}0.338 \\
(11.850)\end{array}$ & $\begin{array}{l}-15.525 \\
(14.763)\end{array}$ & $\begin{array}{c}6.552 \\
(15.826)\end{array}$ & $\begin{array}{c}-0.454 \\
(18.714)\end{array}$ \\
\hline Loss $\times$ Predicted Close (Close Loss) & $\begin{array}{l}-16.354 \\
(19.293)\end{array}$ & $\begin{array}{l}12.538 \\
(27.143)\end{array}$ & $\begin{array}{c}45.013 * * \\
(18.930)\end{array}$ & $\begin{array}{c}17.864 \\
(18.479)\end{array}$ & $\begin{array}{l}-19.771 \\
(19.308)\end{array}$ \\
\hline Win $\times$ Predicted Loss (Upset Win) & $\begin{array}{l}-12.978 \\
(18.032)\end{array}$ & $\begin{array}{l}-19.379 \\
(25.162)\end{array}$ & $\begin{array}{c}21.537 \\
(22.813)\end{array}$ & $\begin{array}{l}-52.121 \\
(30.550)\end{array}$ & $\begin{array}{c}3.537 \\
(13.085)\end{array}$ \\
\hline Predicted Close & $\begin{array}{l}-9.131 \\
(15.023)\end{array}$ & $\begin{array}{l}-13.370 \\
(18.063)\end{array}$ & $\begin{array}{l}-15.657 \\
(16.480)\end{array}$ & $\begin{array}{c}5.882 \\
(12.718)\end{array}$ & $\begin{array}{c}-4.712 \\
(15.479)\end{array}$ \\
\hline Predicted Loss & $\begin{array}{l}-8.135 \\
(16.047)\end{array}$ & $\begin{array}{c}23.743 \\
(17.187)\end{array}$ & $\begin{array}{l}-7.801 \\
(16.219)\end{array}$ & $\begin{array}{l}11.252 \\
(19.143)\end{array}$ & $\begin{array}{l}-16.947 \\
(14.345)\end{array}$ \\
\hline Sample Size & 7,329 & 8,162 & 7,518 & 8,770 & 7,726 \\
\hline $\begin{array}{l}\text { Controls: } \\
\text { Season Week and Davs }\end{array}$ & & & & & Yo \\
\hline $\begin{array}{l}\text { Season, Week, and Days of Week } \\
\text { Judge Attributes }\end{array}$ & $\begin{array}{l}\text { Yes } \\
\text { No }\end{array}$ & $\begin{array}{l}\text { Yes } \\
\text { No }\end{array}$ & $\begin{array}{l}\text { Yes } \\
\text { No }\end{array}$ & $\begin{array}{l}\text { Yes } \\
\text { No }\end{array}$ & $\begin{array}{l}\text { Yes } \\
\text { No }\end{array}$ \\
\hline Juvenile Attributes & Yes & Yes & Yes & Yes & Yes \\
\hline Game Attributes & Yes & Yes & Yes & Yes & Yes \\
\hline Offense Fixed Effects & Yes & Yes & Yes & Yes & Yes \\
\hline Judge Fixed Effects & Yes & Yes & Yes & Yes & Yes \\
\hline
\end{tabular}

Standard errors, which are clustered at the judge level, are reported in parentheses. See notes to Table 4 and the text for data and control variable details. *significant at $10 \%, * *$ significant at $5 \%, * * *$ significant at $1 \%$. 
Table 12

Falsification Test-The Effect of Past-and-Next Weeks’ LSU Football Game Results on Disposition Length Imposed by Judges

\begin{tabular}{|c|c|c|c|}
\hline \multirow[t]{2}{*}{$\begin{array}{l}\text { Dependent Variable: } \\
\text { Disposition Length }\end{array}$} & \multicolumn{3}{|c|}{$\begin{array}{c}\text { Coefficients } \\
\text { (Standard Errors) }\end{array}$} \\
\hline & (1) & $(2)$ & (3) \\
\hline Loss $\times$ Predicted Win (Upset Loss) & $\begin{array}{c}35.160 * * \\
(16.134)\end{array}$ & $\ldots \ldots$ & $\begin{array}{l}36.387 * * \\
(16.343)\end{array}$ \\
\hline Loss $\times$ Predicted Close (Close Loss) & $\begin{array}{c}-2.875 \\
(24.641)\end{array}$ & $\ldots$. & $\begin{array}{c}-2.924 \\
(26.308)\end{array}$ \\
\hline Win $\times$ Predicted Loss (Upset Win) & $\begin{array}{l}-12.544 \\
(24.345)\end{array}$ & $\ldots \ldots$ & $\begin{array}{l}-12.669 \\
(24.461)\end{array}$ \\
\hline Predicted Close & $\begin{array}{c}-1.064 \\
(16.908)\end{array}$ & $\ldots$. & $\begin{array}{c}-1.185 \\
(17.380)\end{array}$ \\
\hline Predicted Loss & $\begin{array}{c}14.085 \\
(17.202)\end{array}$ & $\ldots .$. & $\begin{array}{c}14.884 \\
(17.732)\end{array}$ \\
\hline Loss $\times$ Predicted Win (Upset Loss)-Following Week & $\ldots .$. & $\begin{array}{c}-1.213 \\
(16.434)\end{array}$ & $\begin{array}{c}3.259 \\
(17.208)\end{array}$ \\
\hline Loss $\times$ Predicted Close (Close Loss)-Following Week & $\ldots$. & $\begin{array}{l}-3.060 \\
(21.419)\end{array}$ & $\begin{array}{c}-6.538 \\
(21.203)\end{array}$ \\
\hline Win $\times$ Predicted Loss (Upset Win)-Following Week & $\ldots .$. & $\begin{array}{c}14.694 \\
(24.820)\end{array}$ & $\begin{array}{c}10.083 \\
(26.318)\end{array}$ \\
\hline Predicted Close-Following Week & $\ldots .$. & $\begin{array}{c}0.383 \\
(17.524)\end{array}$ & $\begin{array}{c}3.469 \\
(17.806)\end{array}$ \\
\hline Predicted Loss-Following Week & $\ldots .$. & $\begin{array}{l}-14.035 \\
(17.277)\end{array}$ & $\begin{array}{l}-13.547 \\
(17.334)\end{array}$ \\
\hline Sample Size & 6,420 & 6,420 & 6,420 \\
\hline
\end{tabular}

The sample is restricted to all juvenile dispositions following Saturday games played in consecutive weeks during the seasons from 1996 to 2012. Standard errors, which are clustered at the judge level, are reported in parentheses. All specifications control for day of the week, week and season effects, (time-variant) judge, juvenile characteristics and offense and judge fixed effects. There are 161 detailed offense types and 201 judges in the effective sample. See notes to Table 4 and the text for data and control variable details. *significant at $10 \%, * *$ significant at $5 \%, * * *$ significant at $1 \%$. Column (1) is the baseline specification where disposition lengths assigned by judges in a week are regressed on previous week's game results. In column (2) disposition length assigned by judges in a week are regressed on next week's game results. 
Figure 1

Distribution of Disposition Length Imposed by Judges

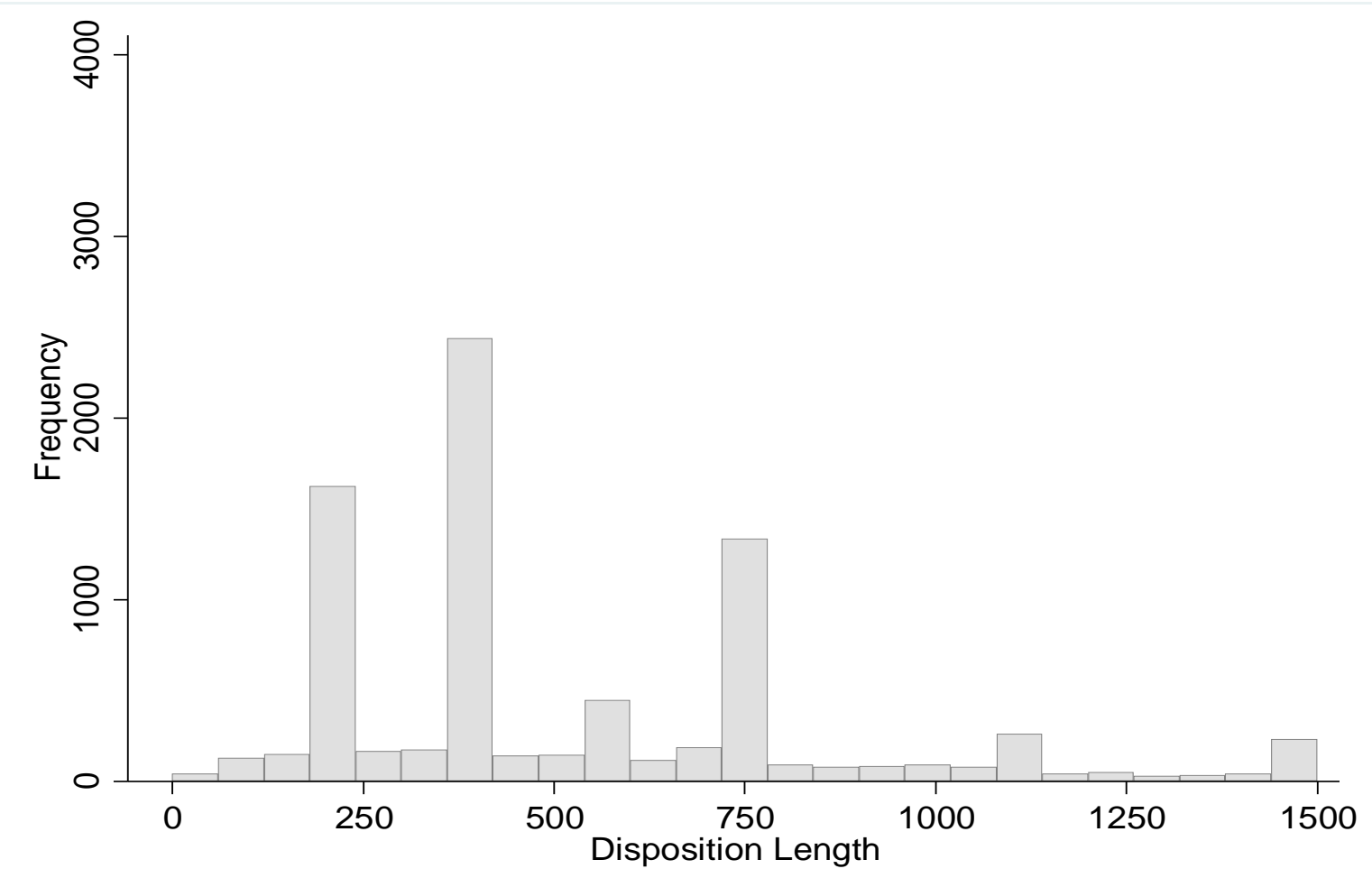

All dispositions are during the weekdays following a Saturday game for the seasons from 1996 to 2012. 
Figure 2

Realized Score Differential (Opponent Team - LSU) and Pregame Point Spread

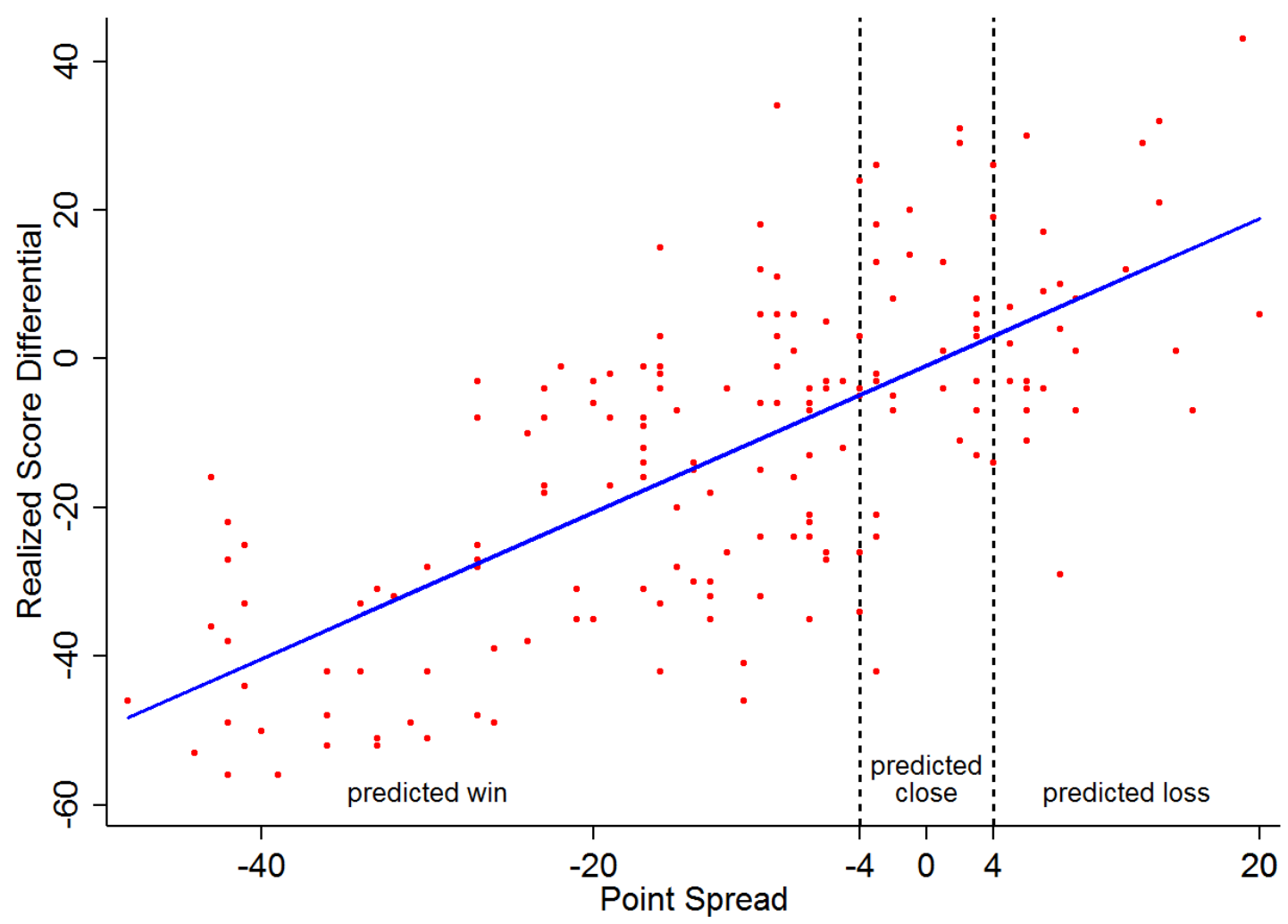

The plotted regression has a slope of 0.98 (s.e. $=0.07$ ). The $\mathrm{R}^{2}$ from the regression is 0.49 . 
Figure 3A

Predicted Win

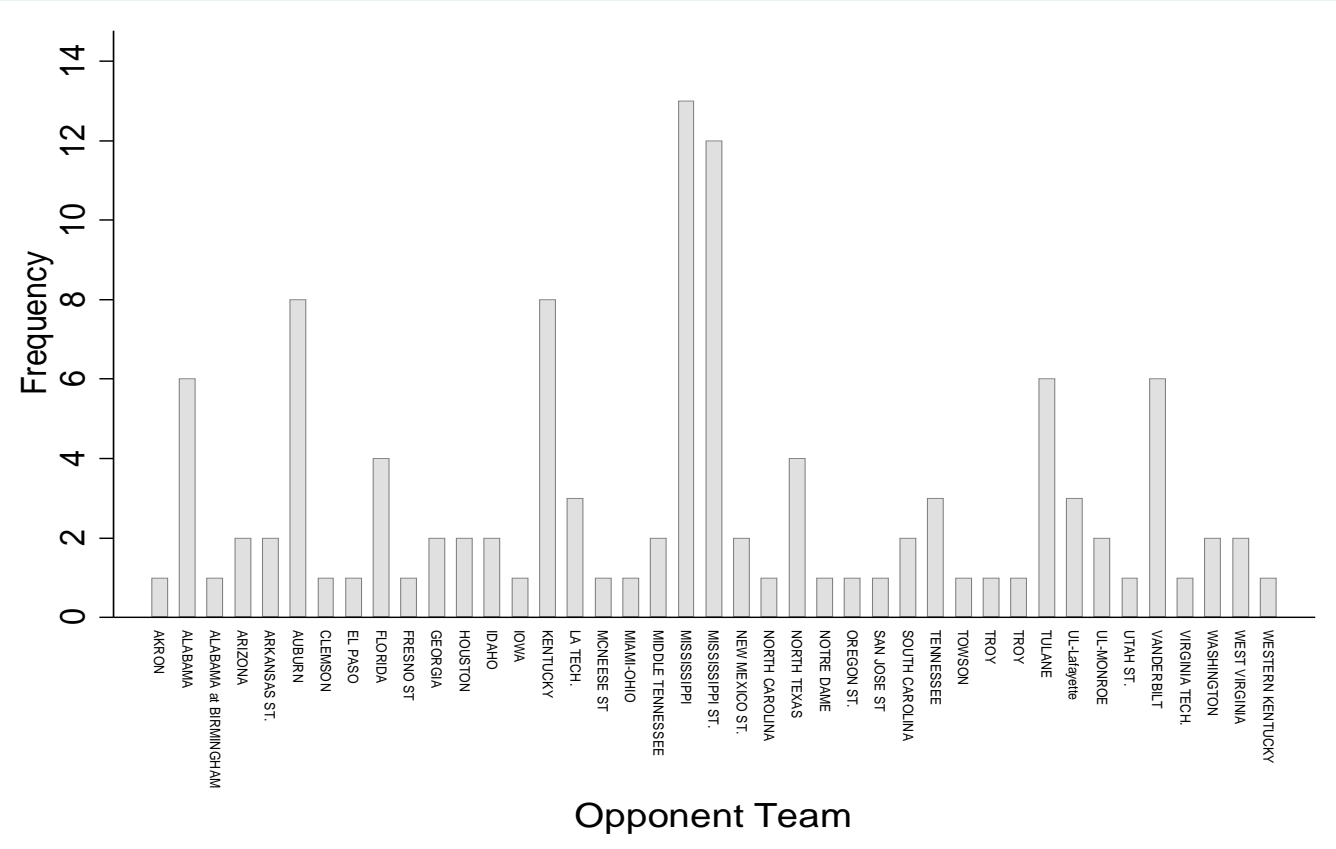

Figure 3B

Actual Loss (Upset Loss)

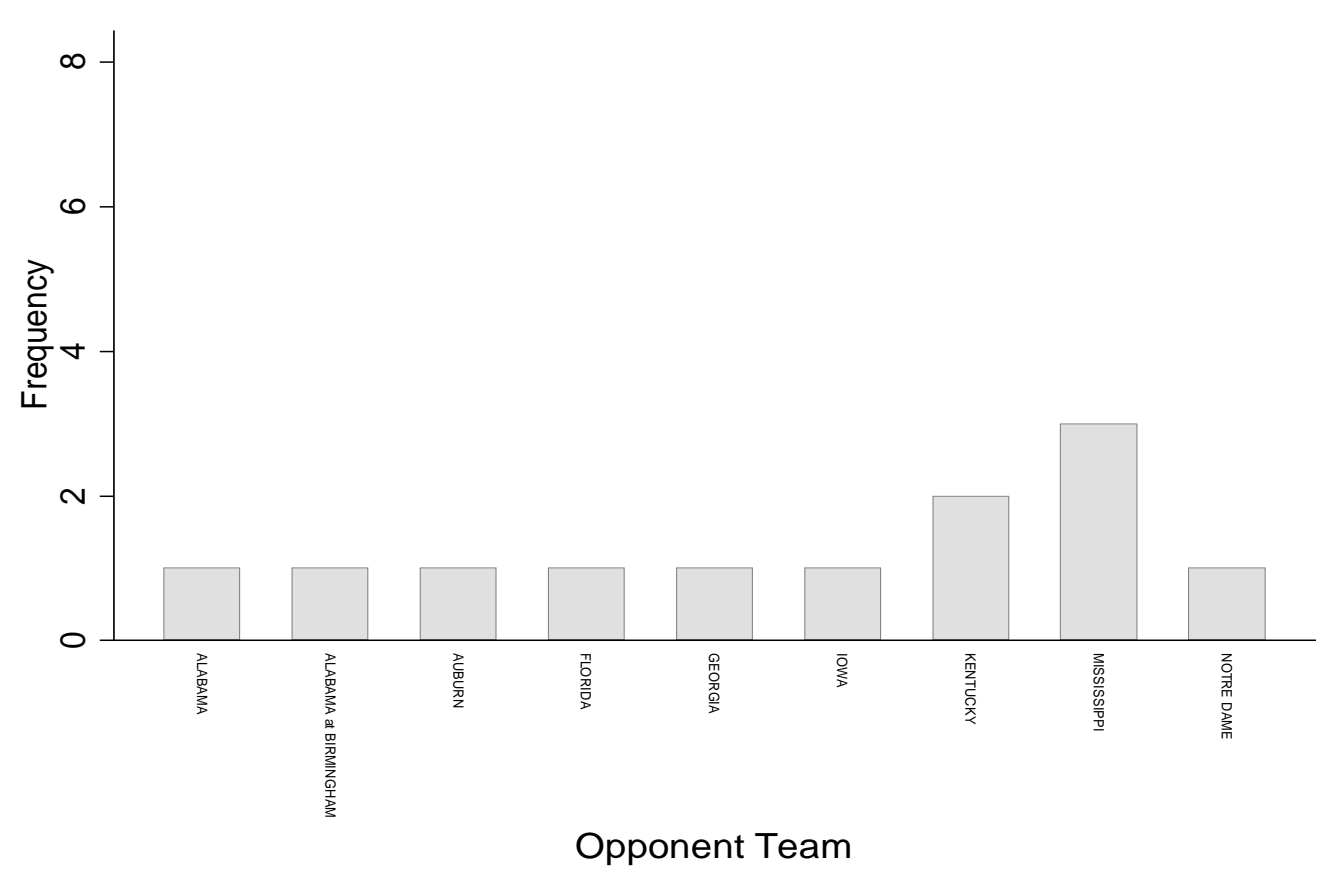

Predicted Win denotes games where the point spread for LSU is -4 or less. 
Figure 4A

Predicted Close

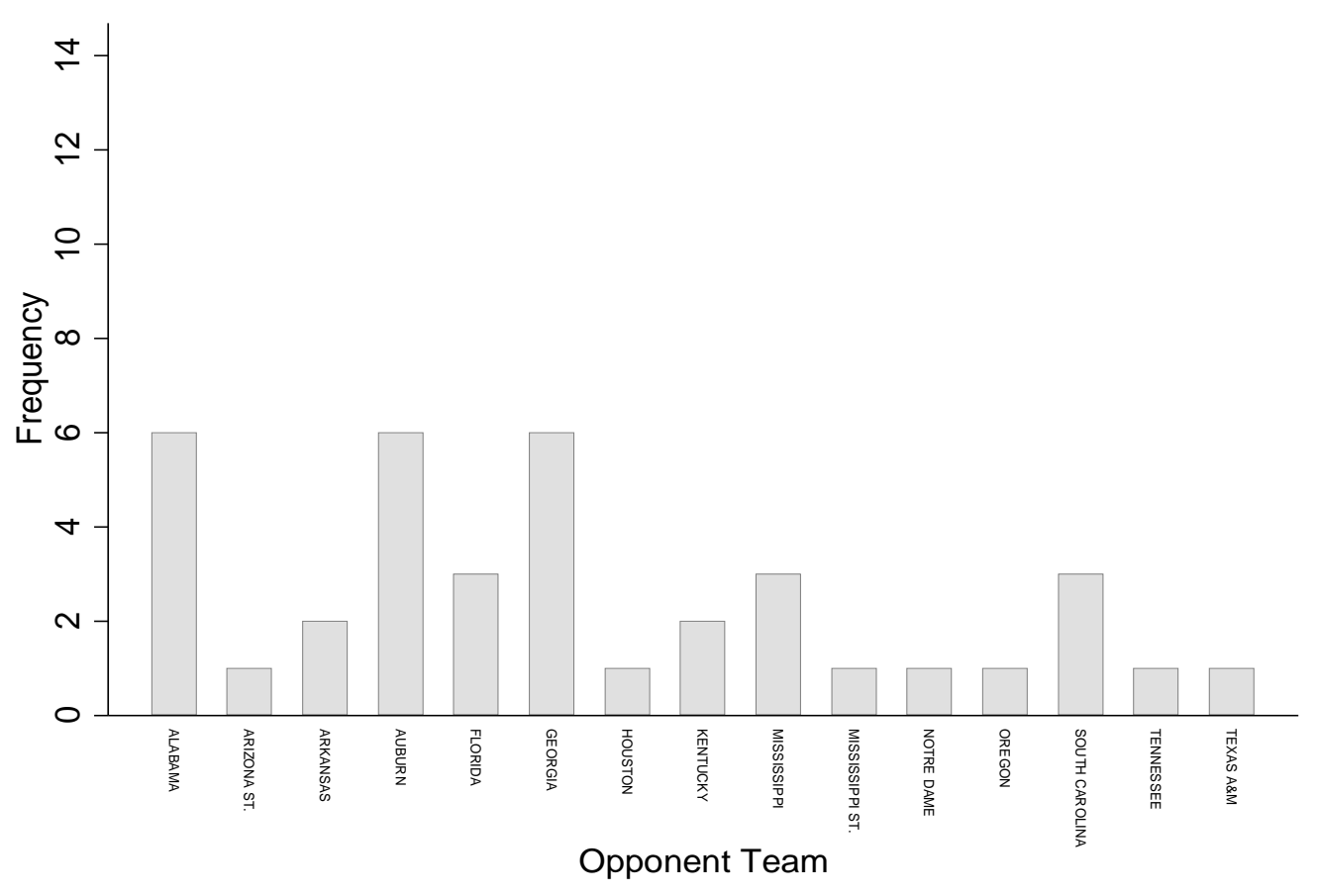

Figure 4B

Actual Loss (Close Loss)

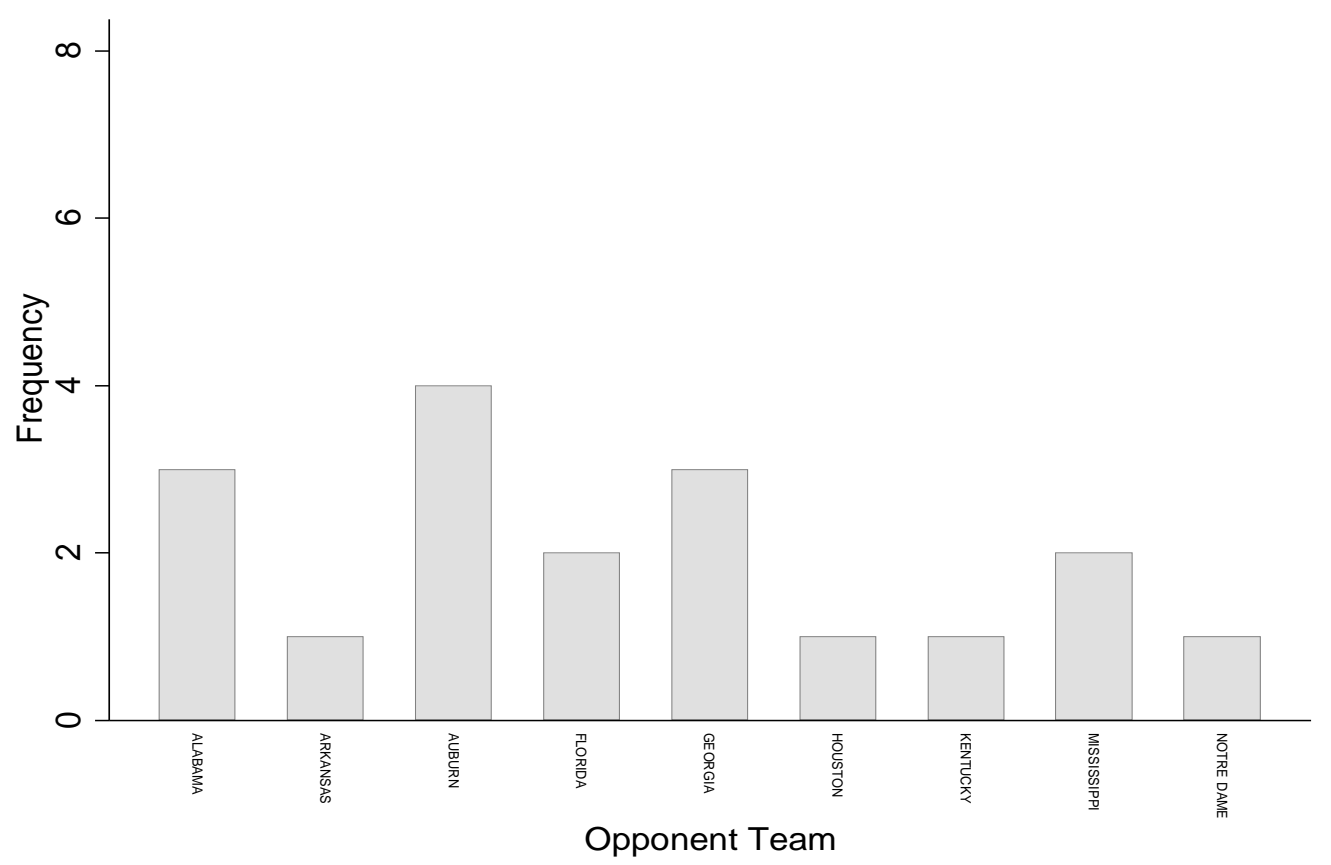

Predicted Close denotes games where point spread for LSU is between -4 and 4 . 
Figure 5A

Predicted Loss

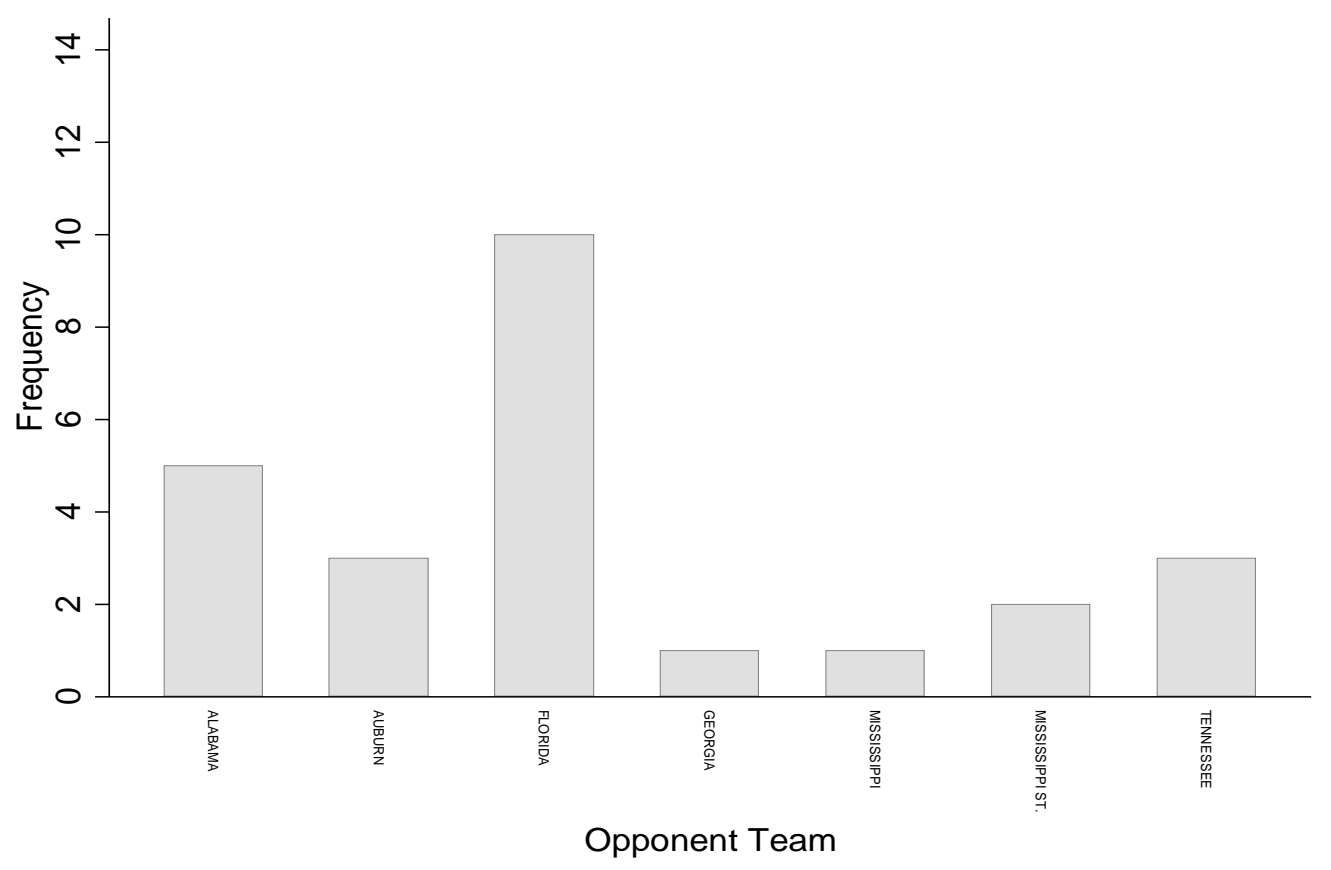

Figure 5B

Actual Win (Upset Win)

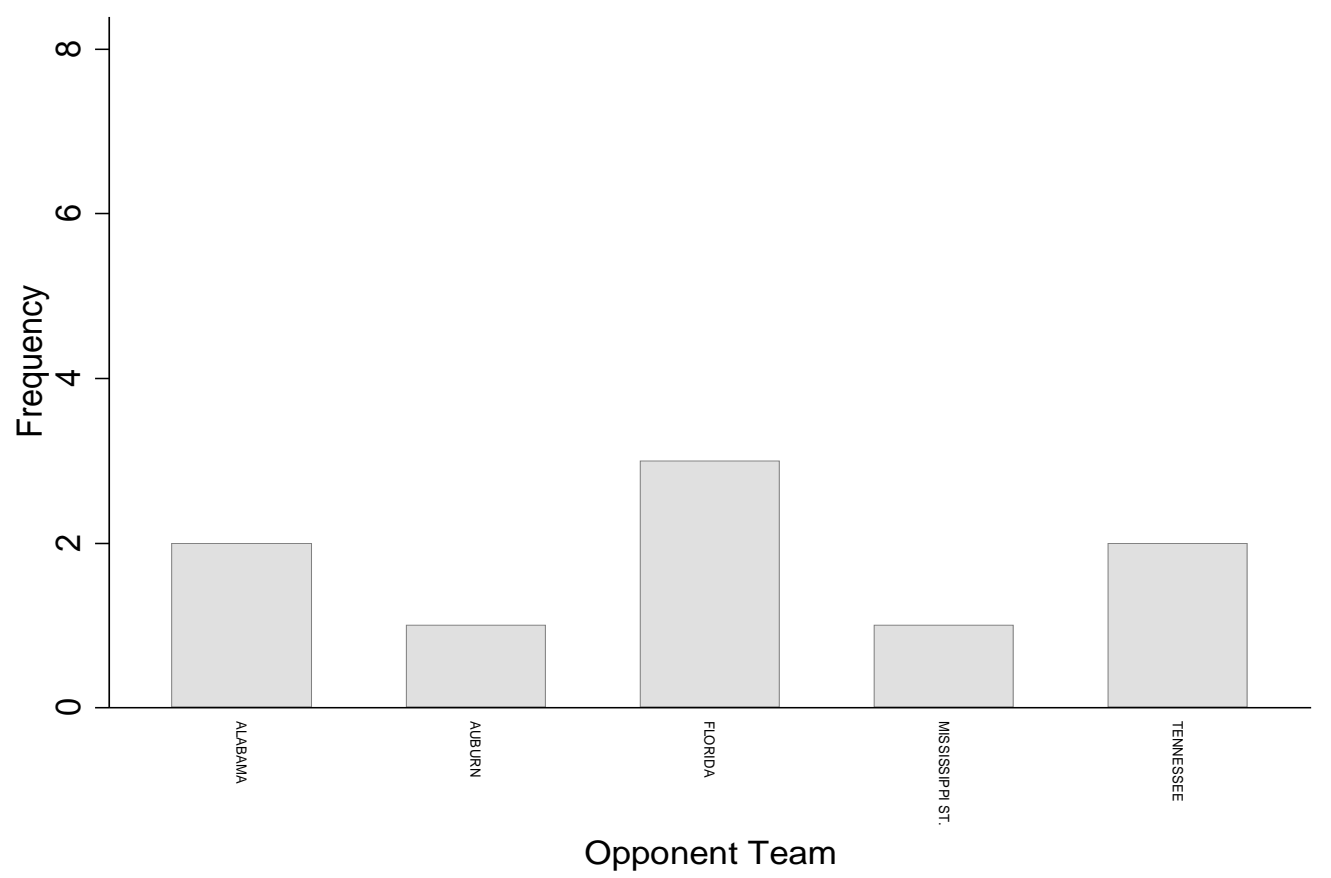

Predicted Loss denotes games where point spread for LSU is 4 or more. 


\section{Figure 6}

Increase in Disposition Length for an LSU Loss vs. a Win as a Function of the Pregame Point Spread

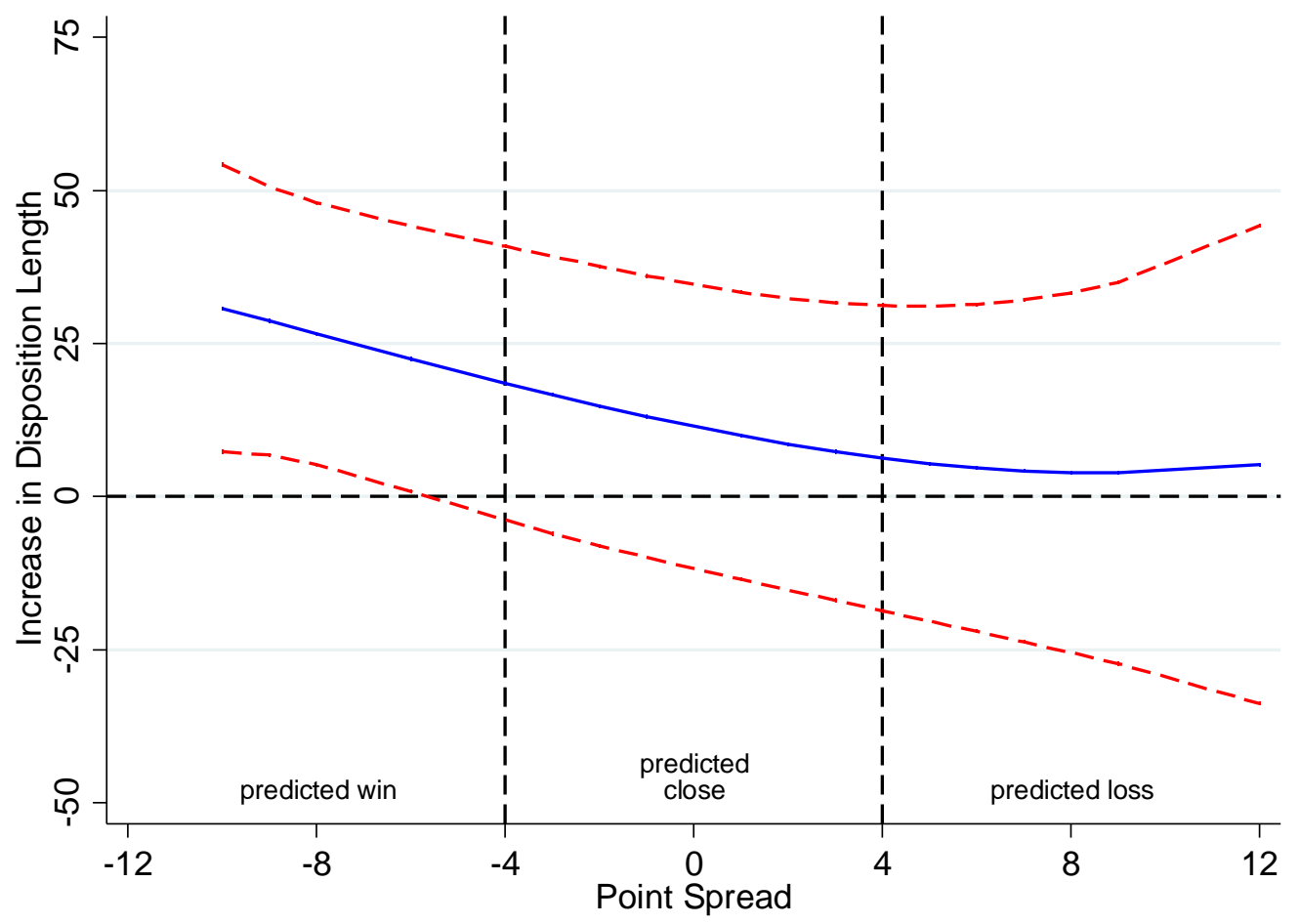

The estimates are obtained from a specification with a third-order polynomial in the point spread and an interaction between the polynomial and an indicator for LSU loss. The dashed lines are pointwise $90 \%$ confidence intervals. 


\section{Appendix Table A1}

The Effect of Emotional Shocks from LSU Football Games on Disposition Length Imposed by Judges:

Alternative Estimations

\begin{tabular}{|c|c|c|c|c|c|c|c|}
\hline $\begin{array}{l}\text { Dependent Variable: } \\
\text { Disposition Length }\end{array}$ & $\begin{array}{c}\text { Poisson } \\
\text { Regression }\end{array}$ & $\begin{array}{c}\text { Log of } \\
\text { Dep. Var. }\end{array}$ & $\begin{array}{c}\text { Exclude } \\
\text { Katrina } \\
\text { Years }\end{array}$ & $\begin{array}{c}\text { Exclude } \\
\text { Bowl } \\
\text { Games }\end{array}$ & $\begin{array}{c}\text { Include } \\
\text { Serious } \\
\text { Offenses }\end{array}$ & $\begin{array}{c}\text { Include } \\
\text { Offenders } \\
\text { with Crime } \\
\text { History }\end{array}$ & $\begin{array}{c}\text { Exclude } \\
\text { Weeks with } \\
\text { Docket } \\
\text { Congestion }\end{array}$ \\
\hline & $(1)$ & $(2)$ & (3) & $(4)$ & $(5)$ & $(6)$ & $(7)$ \\
\hline Loss Predicted Win (Upset Loss) & $\begin{array}{c}0.062 * * * \\
(0.023)\end{array}$ & $\begin{array}{c}0.063 * * * \\
(0.023)\end{array}$ & $\begin{array}{l}34.643 * * \\
(13.488)\end{array}$ & $\begin{array}{l}34.657 * * \\
(13.746)\end{array}$ & $\begin{array}{l}33.075^{* *} \\
(13.925)\end{array}$ & $\begin{array}{l}33.038^{* *} \\
(13.325)\end{array}$ & $\begin{array}{l}31.952 * * \\
(13.711)\end{array}$ \\
\hline Loss Predicted Close (Close Loss) & $\begin{array}{c}0.012 \\
(0.033)\end{array}$ & $\begin{array}{c}0.020 \\
(0.036)\end{array}$ & $\begin{array}{c}17.721 \\
(21.619)\end{array}$ & $\begin{array}{c}7.696 \\
(20.070)\end{array}$ & $\begin{array}{c}2.685 \\
(17.925)\end{array}$ & $\begin{array}{c}5.296 \\
(15.841)\end{array}$ & $\begin{array}{c}2.835 \\
(17.759)\end{array}$ \\
\hline Win Predicted Loss (Upset Win) & $\begin{array}{l}-0.020 \\
(0.039)\end{array}$ & $\begin{array}{l}-0.024 \\
(0.037)\end{array}$ & $\begin{array}{l}-11.135 \\
(21.262)\end{array}$ & $\begin{array}{c}-9.850 \\
(21.456)\end{array}$ & $\begin{array}{l}-12.437 \\
(21.328)\end{array}$ & $\begin{array}{c}-1.630 \\
(20.399)\end{array}$ & $\begin{array}{l}-15.468 \\
(21.529)\end{array}$ \\
\hline Predicted Close & $\begin{array}{l}-0.017 \\
(0.024)\end{array}$ & $\begin{array}{l}-0.021 \\
(0.031)\end{array}$ & $\begin{array}{l}-12.040 \\
(13.798)\end{array}$ & $\begin{array}{l}-10.697 \\
(13.978)\end{array}$ & $\begin{array}{c}-7.683 \\
(13.413)\end{array}$ & $\begin{array}{l}-10.266 \\
(11.732)\end{array}$ & $\begin{array}{l}-11.745 \\
(13.861)\end{array}$ \\
\hline Predicted Loss & $\begin{array}{c}0.013 \\
(0.027)\end{array}$ & $\begin{array}{c}0.020 \\
(0.027)\end{array}$ & $\begin{array}{c}1.981 \\
(15.223)\end{array}$ & $\begin{array}{c}4.869 \\
(14.578)\end{array}$ & $\begin{array}{c}3.659 \\
(14.348)\end{array}$ & $\begin{array}{c}-1.962 \\
(14.530)\end{array}$ & $\begin{array}{c}10.292 \\
(15.021)\end{array}$ \\
\hline Sample Size & 8,228 & 8,228 & 7,443 & 7,867 & 8,260 & 9,313 & 7,625 \\
\hline $\begin{array}{l}\text { Controls: } \\
\text { Season, Week, and Days of Week } \\
\text { Judge Attributes } \\
\text { Juvenile Attributes } \\
\text { Game Attributes } \\
\text { Offense Fixed Effects } \\
\text { Judge Fixed Effects }\end{array}$ & $\begin{array}{c}\text { Yes } \\
\text { No } \\
\text { Yes } \\
\text { Yes } \\
\text { Yes } \\
\text { Yes }\end{array}$ & $\begin{array}{c}\text { Yes } \\
\text { No } \\
\text { Yes } \\
\text { Yes } \\
\text { Yes } \\
\text { Yes }\end{array}$ & $\begin{array}{c}\text { Yes } \\
\text { No } \\
\text { Yes } \\
\text { Yes } \\
\text { Yes } \\
\text { Yes }\end{array}$ & $\begin{array}{c}\text { Yes } \\
\text { No } \\
\text { Yes } \\
\text { Yes } \\
\text { Yes } \\
\text { Yes }\end{array}$ & $\begin{array}{c}\text { Yes } \\
\text { No } \\
\text { Yes } \\
\text { Yes } \\
\text { Yes } \\
\text { Yes }\end{array}$ & $\begin{array}{c}\text { Yes } \\
\text { No } \\
\text { Yes } \\
\text { Yes } \\
\text { Yes } \\
\text { Yes }\end{array}$ & $\begin{array}{c}\text { Yes } \\
\text { No } \\
\text { Yes } \\
\text { Yes } \\
\text { Yes } \\
\text { Yes }\end{array}$ \\
\hline
\end{tabular}

Standard errors, which are clustered at the judge level, are reported in parentheses. Pseudo $\mathrm{R}^{2}$ is reported in Column 1 . See notes to Table 4 and the text for data and control variable details. *significant at $10 \%, * *$ significant at $5 \%, * * *$ significant at $1 \%$. 
Appendix Table A2

The Effect of Emotional Shocks from LSU Football Games on Disposition Length Imposed by Judges: Including bye Weeks

\begin{tabular}{lc}
\hline \hline $\begin{array}{l}\text { Dependent Variable: } \\
\text { Disposition Length }\end{array}$ & $\begin{array}{c}\text { Coefficients } \\
\text { (Standard Errors) }\end{array}$ \\
\hline Loss $\times$ Predicted Win (Upset Loss) & $31.780^{* *}$ \\
& $(13.206)$ \\
Loss $\times$ Predicted Close (Close Loss) & 1.602 \\
& $(18.099)$ \\
Win $\times$ Predicted Loss (Upset Win) & -9.580 \\
& $(28.651)$ \\
Predicted Win & 0.706 \\
& $(47.967)$ \\
Predicted Close & -6.745 \\
& $(45.983)$ \\
Predicted Loss & 3.716 \\
& $(53.663)$ \\
Sample Size & 9,234 \\
Controls: & \\
Season, Week, and Days of Week & Yes \\
Judge Attributes & No \\
Juvenile Attributes & Yes \\
Game Attributes & Yes \\
Offense Fixed Effects & Yes \\
Judge Fixed Effects & Yes \\
\hline \hline thdard errors, which are clustered at the judge level, are reported in parentheses. Bye Weeks \\
the omitted category. See notes to Table 4 and the text for data and control variable details. \\
\end{tabular}

